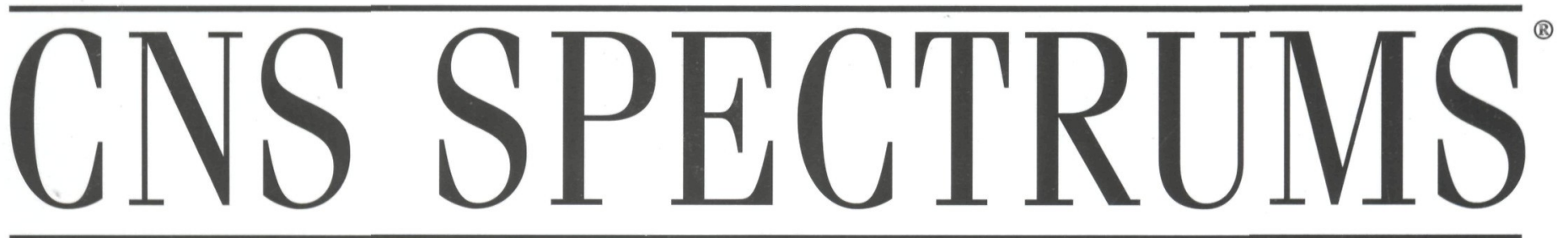

The International Journal of Neuropsychiatric Medicine

\title{
7
}

\section{Mechanisms and Presentations of Catatonia}

The Universal Field Hypothesis of Catatonia and

Neuroleptic Malignant Syndrome

B. T. Carroll

Brain Imaging in Catatonia:

Current Findings and a Pathophysiologic Model

G. Northoff

Catatonia in Affective Disorder:

New Findings and a Review of the Literature

S. Krüger and P. Bräunig

Is Lorazepam a Treatment for Neuroleptic

Malignant Syndrome?

A. Francis, S. Chandragiri,

S. Rizvi, M. Koch, and G. Petrides

An Analysis of 17 Catatonic Patients Diagnosed With

Neuroleptic Malignant Syndrome

D. A. C. White and A. H. Robins

Catatonic Signs in Medical and Psychiatric Catatonias

B. T. Carrol, J. C. Kennedy, and H. W. Goforth 
You see it as maintaining cognitive

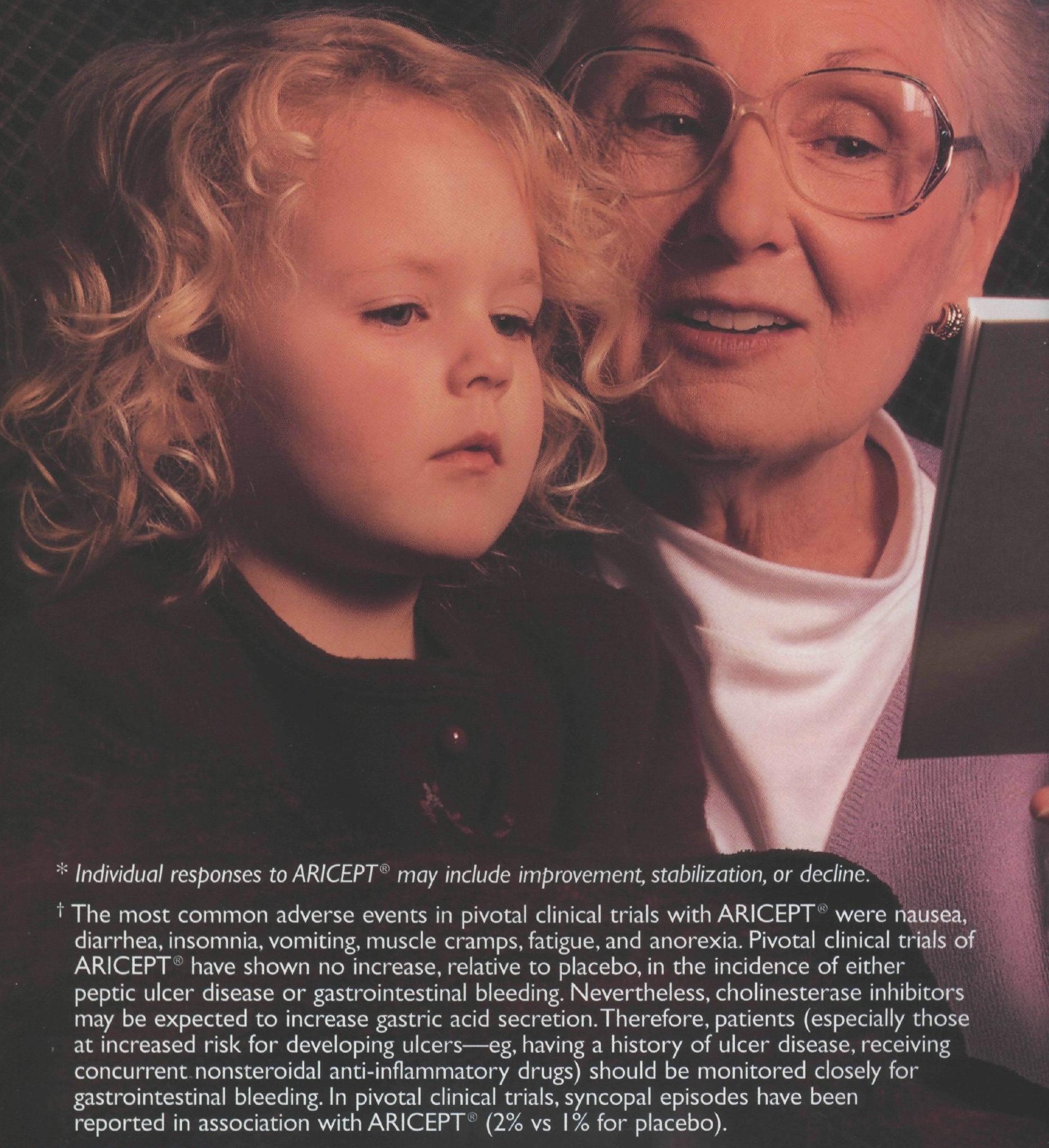




\section{function.}

She sees it as

a bedtime story.

\section{ARICEPT ${ }^{\circledast}$. Helping to make}

a difference for people living

with Alzheimer's

- Slows the worsening of symptoms*

- Proven to maintain cognition in placebo-controlled studies

- Well tolerated ${ }^{\dagger}$

- Proven safety profile

- Once-daily dosing

- 3 years of real-world use

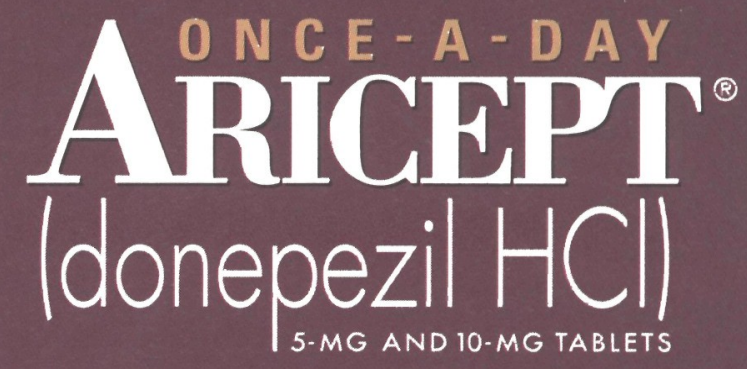

Therapy to REMEMBER 


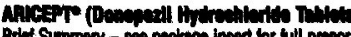

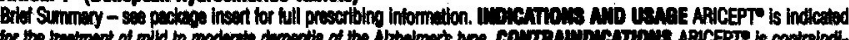

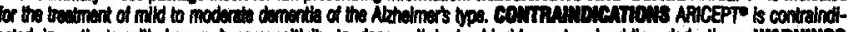

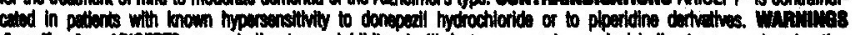
A

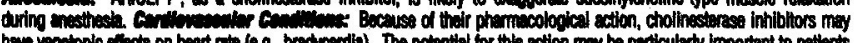

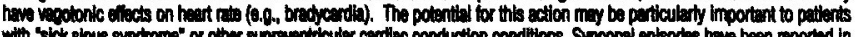

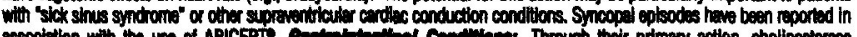

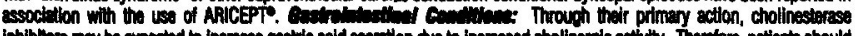

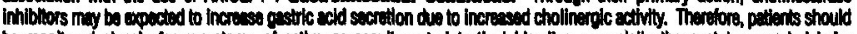

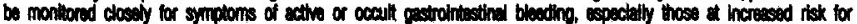

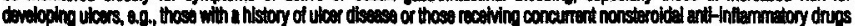

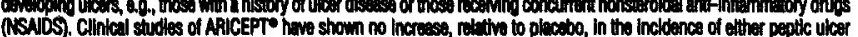
diseese of asestrintiostinal bleeding. ARICEPT as a predlcteble consequence of th pharmacological properties ben shoun to produce darthe froquently with the $10 \mathrm{mo} / \mathrm{day}$ dose then with the $5 \mathrm{mo}$ /tay dose, In most. somelimes lasting on to thre

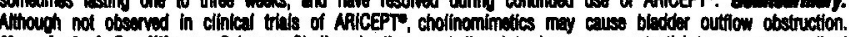

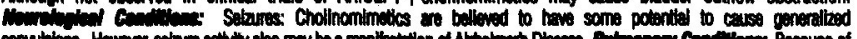

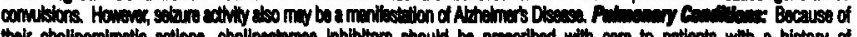

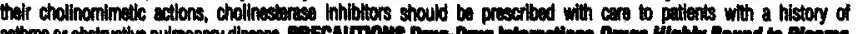

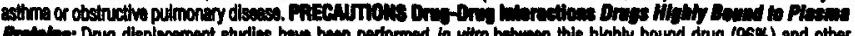

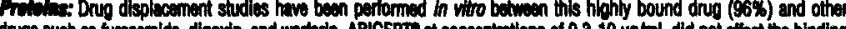
drugs such as furosemida, dipoxin, and waterin. ARICEPT at concentrations of $0.3-10 \mathrm{ug} / \mathrm{mL}$ did not affect the binding of furoesemldo $(5 \mathrm{ug} / \mathrm{mL})$, digoxin $(2 \mathrm{mo} / \mathrm{mL})$, and wartarin $(3 \mathrm{ur} / \mathrm{mL})$ to human albumin. Simllarly, the binding of

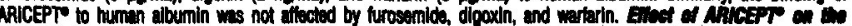
A.

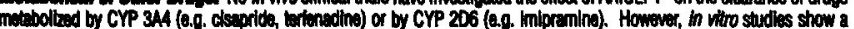
low th of binding to the

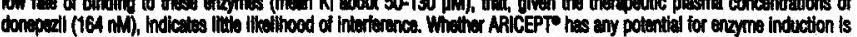

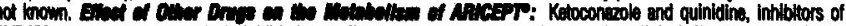
CYP450, 3M4 and 206, respectively, inhibit donepezil metobolism in who. Whether there is a clinical eflact of these inhibitiors

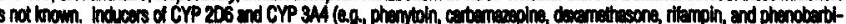

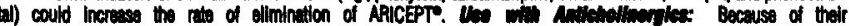

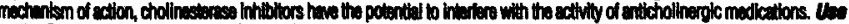

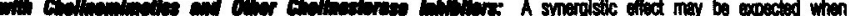

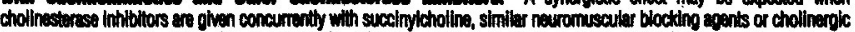

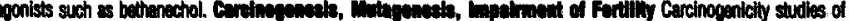

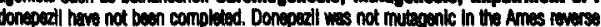

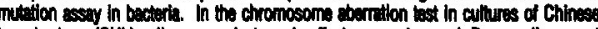

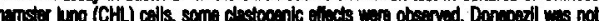

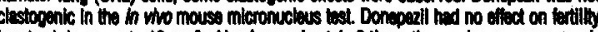

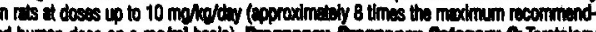

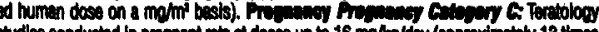

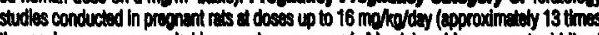

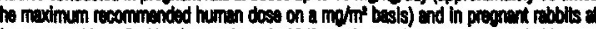

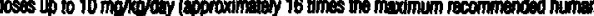
dose on a ma/mi bests) did not disclose any ovidence for a tratopenic potential of

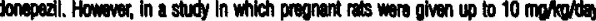
(approximstaly 8 times the maximum reconmended human dose on a $\mathrm{ma} / \mathrm{m}^{2}$ besls) from dy 17 of gestation through day 20 postontum, there was a slight increaso in still

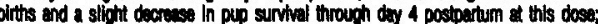

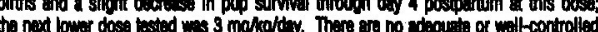

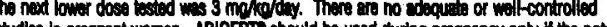
rist to the pres. (a) ARICEPT

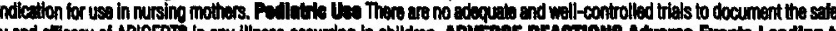

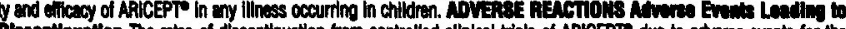

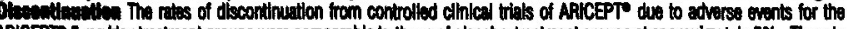
ARICEPT 5 moley treetment groups ware comparable to those of placebo-treednent groups at approxinatoly $5 \%$. The rato

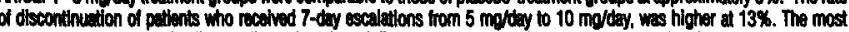
common adverse events beding to discontinuation, defined as those cecurring in at least $2 \%$ of patients and at twice the

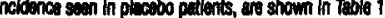

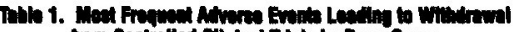

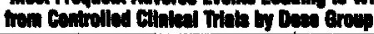

\begin{tabular}{|c|c|c|c|}
\hline 69 & Pacente & 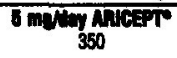 & 10 anday $A$ ALCAT \\
\hline $\begin{array}{l}\text { Nousen } \\
\text { Diarnhen } \\
\text { Vomiting }\end{array}$ & $\begin{array}{l}1 \% \\
0 \% \\
<1 \%\end{array}$ & $\begin{array}{l}1 \% \\
<1 \% \\
<1 \%\end{array}$ & $\begin{array}{l}3 \% \\
3 \% \\
2 \%\end{array}$ \\
\hline
\end{tabular}

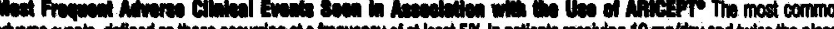

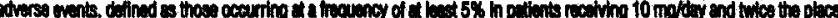

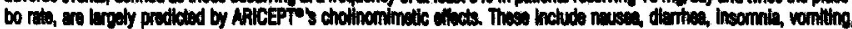

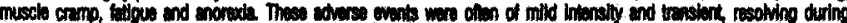

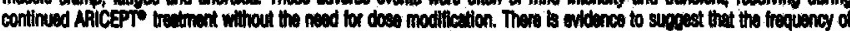

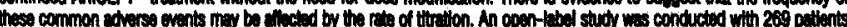

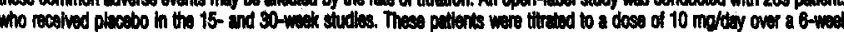

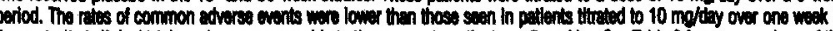
the controlled clinical trials and were comparbils to those seen in petionts on 5 mo/tay. See Teble 2 for a comperison of the most cormmon adverse events tollowing ons and six week ttredion regimens.

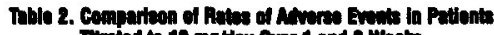

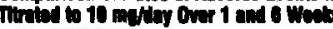

\begin{tabular}{|c|c|c|c|c|}
\hline 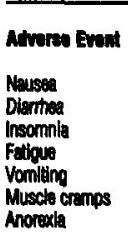 & $\begin{array}{c}\text { Placato } \\
\text { (n-315) } \\
6 \% \\
5 \% \\
6 \% \\
3 \% \\
3 \% \\
2 \% \\
2 \%\end{array}$ & $\begin{array}{c}\text { No thotion } \\
\text { 5 mo/doy } \\
\text { (n-si1) } \\
5 \% \\
8 \% \\
6 \% \\
4 \% \\
3 \% \\
6 \% \\
3 \%\end{array}$ & $\begin{array}{c}\text { Ono-weac throtion } \\
10 \text { ma/dey } \\
\text { (n-315) } \\
19 \% \\
15 \% \\
14 \% \\
8 \% \\
8 \% \\
8 \% \\
7 \%\end{array}$ & $\begin{array}{c}8 x-10 \text { thration } \\
10 \mathrm{~m} / \mathrm{dw} y \\
(0-2 \%) \\
6 \% \\
9 \% \\
6 \% \\
3 \% \\
5 \% \\
3 \% \\
3 \%\end{array}$ \\
\hline
\end{tabular}

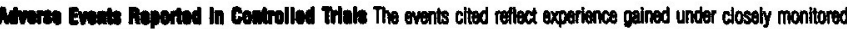
condtions of clinical trias in a bilohly selected peltent poouletion. In actual clinical prectice or In other clinical trials, these heopency sestintes may not epply, es the condtions of use, reporting bohevior, and the kinds of petients treated may

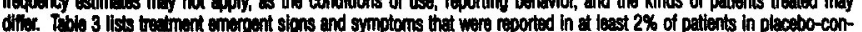

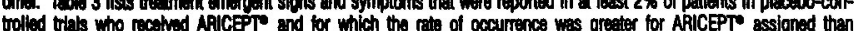

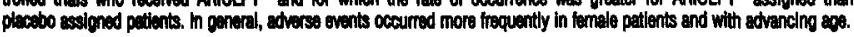

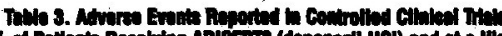

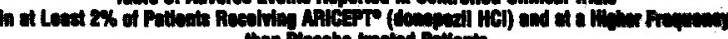

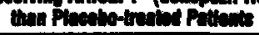

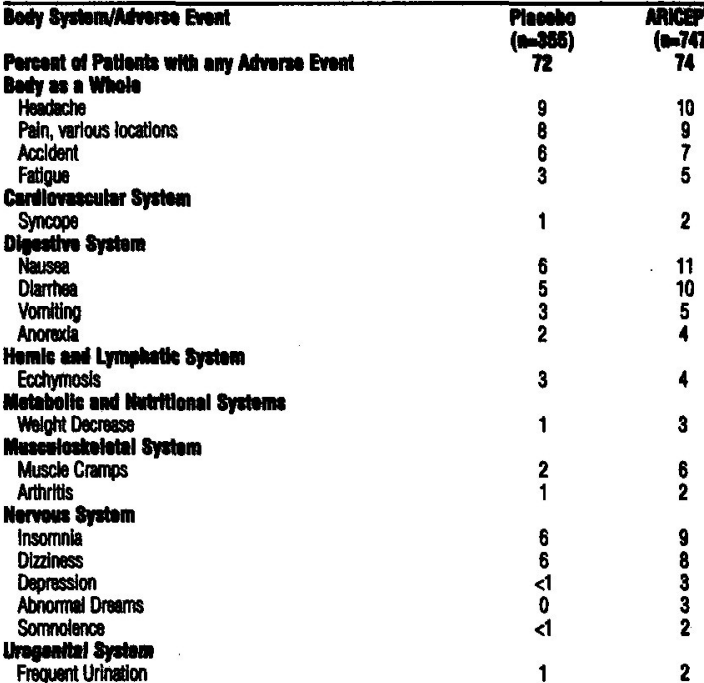

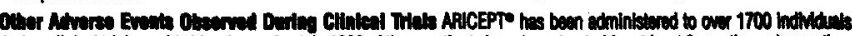

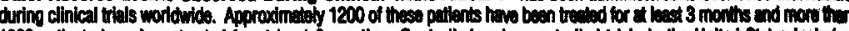

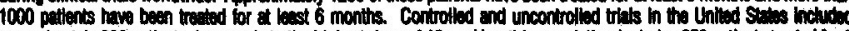

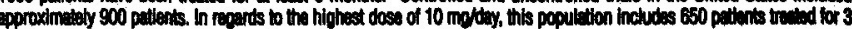

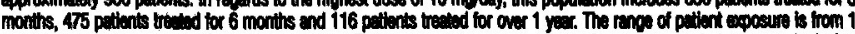

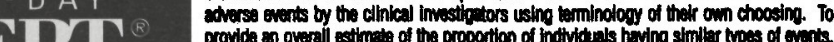

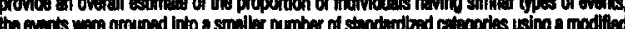
COSTART dictionary and ovent froquencles were calcultad across all studles. These

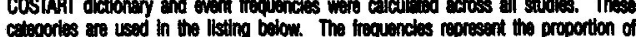
cocoporles are used in the listing below. The frequenclas represent the propotion of

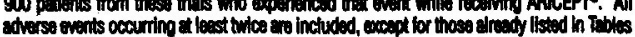

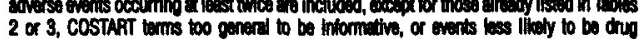

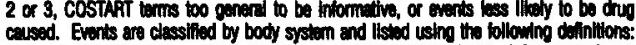

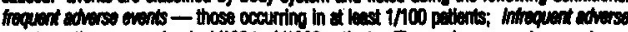
wents - those occuring in $1 / 100$ to $1 / 1000$ petients. Thase chorse events are not necesserily robtad to ARICEPT treatment and in most cases wore obeorved at a simila frequency in placebo-reeded pettents in the controlled studles. No limportent additional adverse wents wore sen in studias

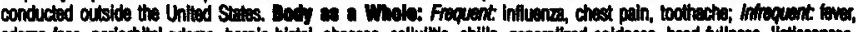

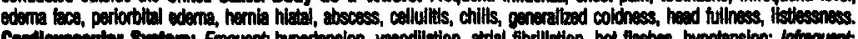

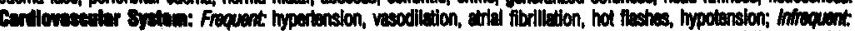

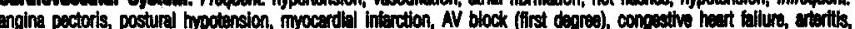

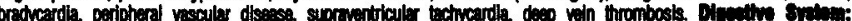

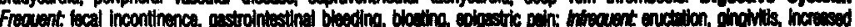

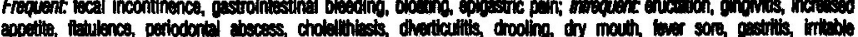

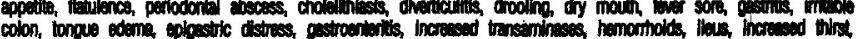

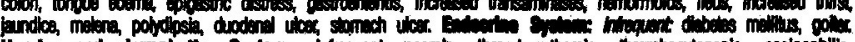

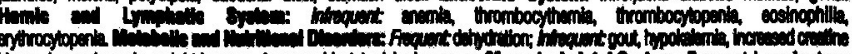

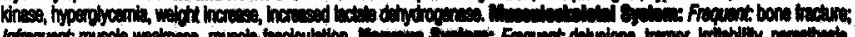

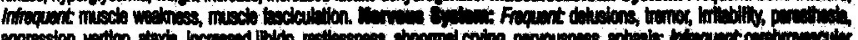

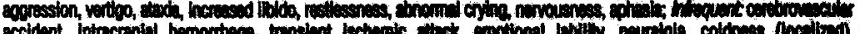

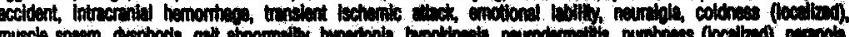

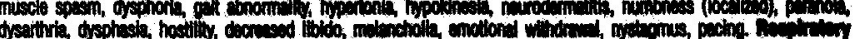

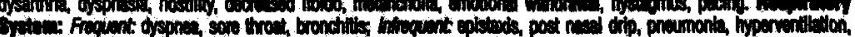

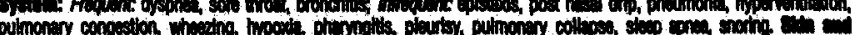

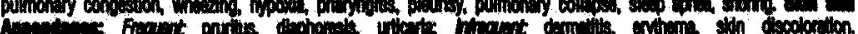

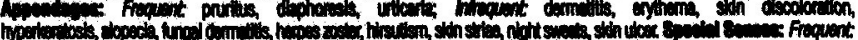

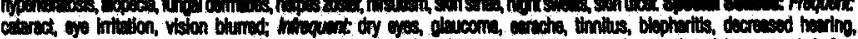

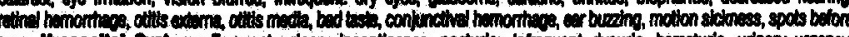

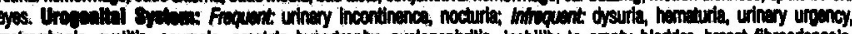

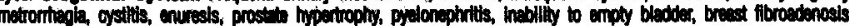

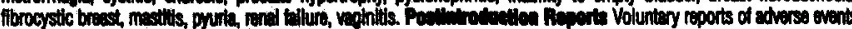

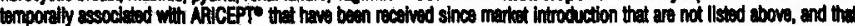

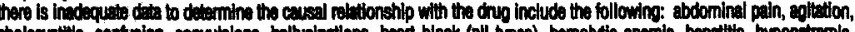

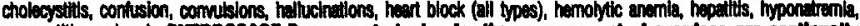

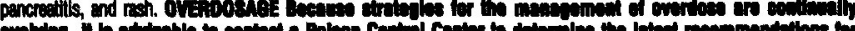

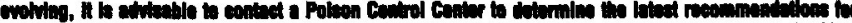

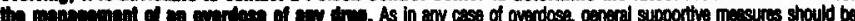

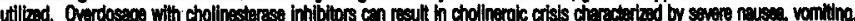

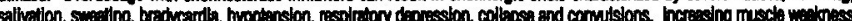

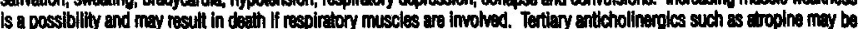

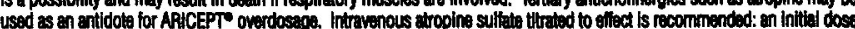
of 1.0 to $2.0 \mathrm{mg} \mathrm{N}$ with subsequent doses besed upon clinical response. Aypleal responses in blood pressure and heent rate have been reportad with other chollinomimetios when co-adninistored with quadernary antichollinargles such as oly-

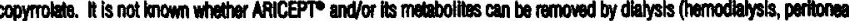

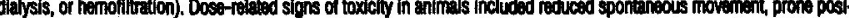

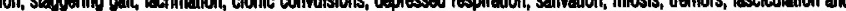

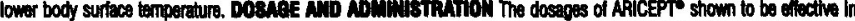
controlled clinical triats ane $5 \mathrm{mg}$ and $10 \mathrm{mg}$ atrininistered once per dy. Controlled clinical trias Indicated thet the $10 \mathrm{mg}$ dose, wth a one week titration, Is likely to be associated with a higher incidences of chollnergic adverse events then the 5 $\mathrm{mo}$ dose. Because steady stete is not achioved for 15 deys and because the incidence of such eflects may to influenced by the rete of dose escalation, treatment with a dose of $10 \mathrm{mo}$ should not be contemplated untl petients have been on a dilly

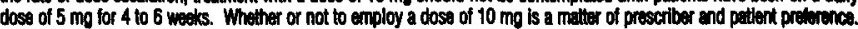
ARICEPT should be baken in the evening, Just prior to retiring, and may be beken with or without food.

Revised September 1809

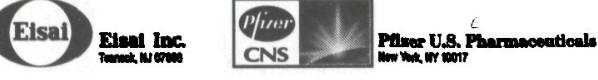

Q 2000, Eead ha and Pillear tho 


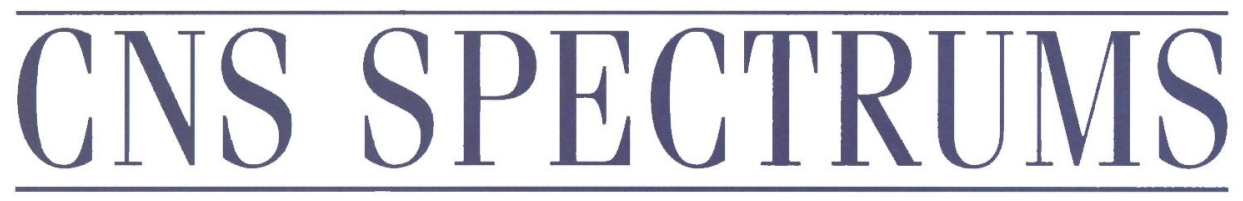

The International Journal of Neuropsychiatric Medicine

EDITOR

Eric Hollander, MD

Mount Sinai School of Medicine New York, NY

\section{INTERNATIONAL EDITOR}

Joseph Zohar, MD

Chaim Sheba Medical Center

Tel Aviv, Israel

\section{ASSOCIATE INTERNATIONAL EDITOR \\ Donatella Marazziti, MD \\ University of Pisa \\ Pisa, Italy}

\section{EDITORIAL DIRECTOR}

James La Rossa Jr.

BOARD OF ADVISORS

Margaret Altemus, MD

Cornell University Medical Center

New York, NY

Mitchell F. Brin, MD

Mount Sinai School of Medicine

New York, NY

John Caronna, MD

New York Hospital-Cornell

Medical Center, New York, NY

Dennis S. Charney, MD

Yale University

New Haven, CT

Emil F. Coccaro, MD

University of Chicago Medical Center

Chicago, IL

Jeffrey L. Cummings, MD

University of California

Los Angeles, CA
Dwight L. Evans, MD

University of Pennsylvania

Philadelphia, PA

Mark George, MD

Medical University of South Carolina Charleston, SC

Jack Gorman, MD

College of Physicians and

Surgeons, Columbia University

New York, NY

Thomas R. Insel, MD

Yerkes Primate Labs

Emory University School of Medicine Atlanta, GA

Lorrin M. Koran, MD

Stanford University Medical School

Stanford, CA

Herbert Y. Meltzer, MD

Vanderbilt University Medical Center Nashville, TN

Stuart A. Montgomery, MD

St. Mary's Hospital Medical School

London, United Kingdom

Dennis L. Murphy, MD

National Institute of Mental Health

Bethesda, MD

Charles B. Nemeroff, MD, PhD

Emory University School of Medicine Atlanta, GA

Humberto Nicolini, MD, PhD

Instituto Mexicano de Psiquiatria

Mexico

Katharine Phillips, MD

Brown University

Providence, RI
Harold A. Pincus, MD

American Psychiatric Association

Washington, DC

Stanley I. Rapoport, MD

National Institute of Mental Health Bethesda, MD

Scott L. Rauch, MD

Massachusetts General Hospital

Charlestown, MA

Alan Schatzberg, MD

Stanford University Medical School Stanford, CA

Dan J. Stein, MB

University of Stellenbosch

Tygerberg, South Africa

Norman Sussman, MD

New York University Medical School New York, NY

Neal R. Swerdlow, MD, PhD

University of California, San Diego

La Jolla, CA

Michael R. Trimble, MD

National Hospital for Neurology

and Neurosurgery

London, United Kingdom

H. M. van Praag, MD

University of Maastricht

Maastricht, The Netherlands

Herman G.M. Westenberg, MD

University Hospital Utrecht

Utrecht, The Netherlands

Richard Wyatt, MD

National Institute of Mental Health Bethesda, MD

Stuart Yudofsky, MD

Baylor College of Medicine

Houston, TX

\section{MBL COMMUNICATIONS}

CEO \& PUBLISHER

James La Rossa Jr.

PRESIDENT \&

ASSOCIATE PUBLISHER

Darren L. Brodeur

MANAGING EDITOR

Claire R. Roberts

ASSOCIATE EDITORIAL DIRECTOR/

ACOUISITIONS EDITOR

Genevieve Romano

SPECIAL PROJECTS EDITOR

Imre Balanli

SENIOR EDITORS

Jenny R. Green

Julie H. Kaufman

\section{ASSISTANT EDITORIAL DIRECTOR}

Kathleen Byrne

\section{ASSOCIATE EDITORS}

Jill Bazar

Keith Papa

EDITORIAL ASSISTANTS

Janeen Labbe

Craig McRea Seip

Joshua Ubaldi

Jessica Wapner

ASSISTANT

ACOUISITIONS EDITOR

Dena Panteleakis

PUBLISHING ASSOCIATE

Jesse D. Soll

NATIONAL ACCOUNTS

MANAGER-

EMERGING MARKETS

Paul McDaniel
ART DIRECTOR

Anthony J. Korsak

ASSISTANT ART DIRECTOR

Benjamin Balcomb

COPY EDITORS

Lauren Cerruto

Michelle Cervone, MD

John Martino

\section{ADMINISTRATIVE ASSISTANT}

Claudette Crawford

\section{CORPORATION COUNSEL}

Kevin F. Saer, Esg.

Davis, Wright, \& Tremaine, LLP

\section{OF COUNSEL}

Susan G. La Rossa, Esq.

Putney, Twombly, Hali \& Hirson 


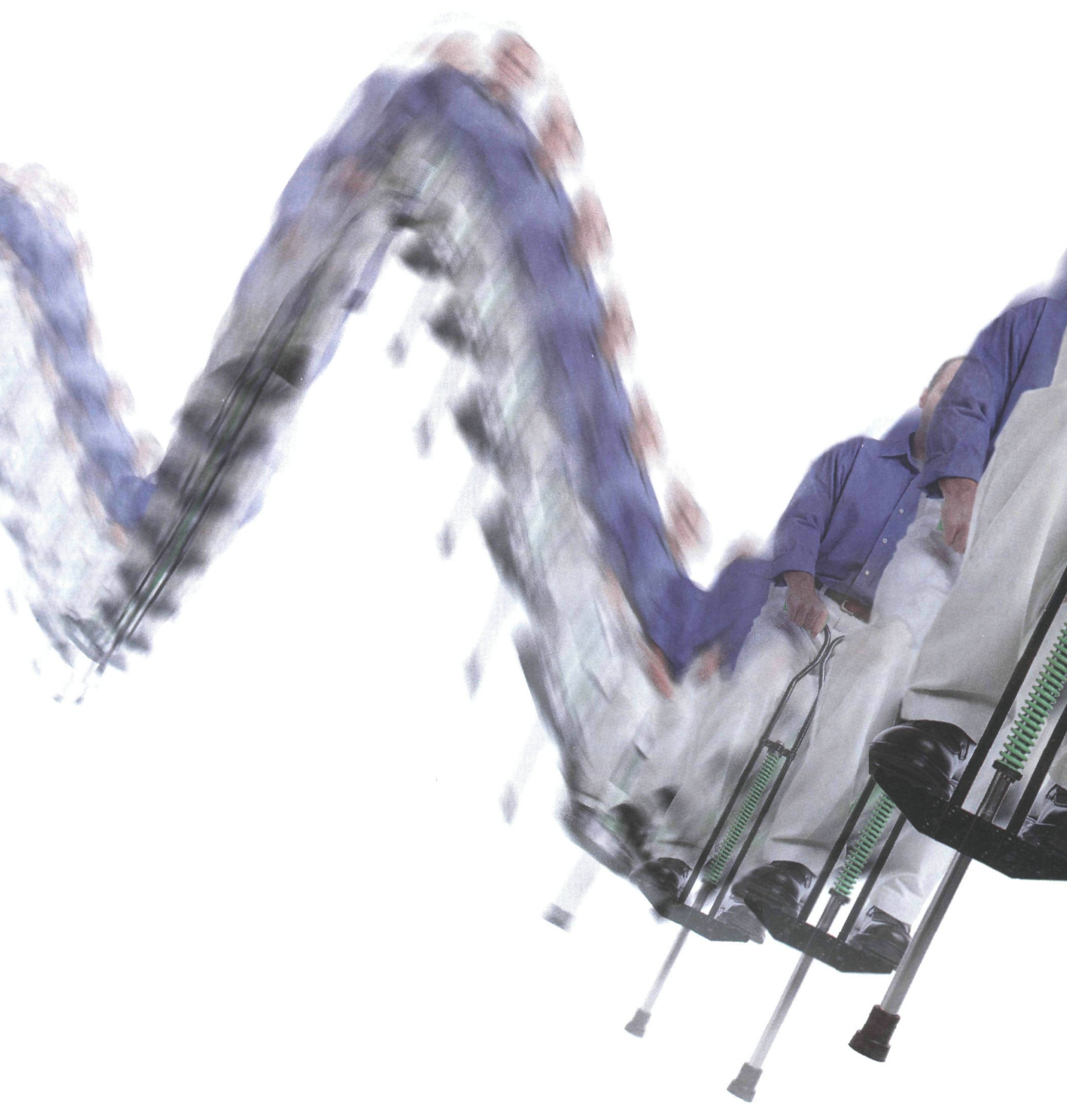

Why expose your patients to the "ups and downs" of traditional carbamazepine therapy?

Peak-to-trough fluctuations in patients receiving immediate-release carbamazepine three times daily can be as great as 2.5 fold $^{1}$ 


\section{Switch to Carbatrol ${ }^{\circledR}$-Second-generation delivery system design that targets the limitations of conventional carbamazepine ${ }^{1-6}$}

- Bioequivalent to immediate-release carbamazepine dosed rigidly Q6h ${ }^{3}$

- Peak-to-trough fluctuations are not compromised ${ }^{3,4}$

- Smooth, consistent plasma concentrations ${ }^{3,4}$

- Extensive drug dispersion, dissolution, and absorption ${ }^{2}$

- Predictable bioavailability ${ }^{5}$

- BID dosing ${ }^{6}$

- No generic equivalent ${ }^{2}$

Absence seizures (petit mal) do not appear to be controlled by carbamazepine. The most frequently reported adverse events (particularly during the initial phases of therapy) are dizziness, drowsiness, unsteadiness, nausea, and vomiting. Adverse events can be minimized by initiating therapy at the lowest possible effective dose.

References: 1. Jensen PK, Moller A, Gram L, Jenson NO, Dam M. Pharmacokinetic comparison of two carbamazepine slow-release formulations. Acta Neurol Scand. 1990;82:135-137. 2. Data on file, Shire Richwood Inc. 3. Garnett WR, Levy B, McLean AM, et al. Pharmacokinetic evaluation of twice-daily extended-release carbamazepine (CBZ) and four-times-daily immediate-release CBZ in patients with epilepsy. Epilepsia. 1998;39(3):274-279. 4. Stevens RE, Limsakun T, Evans G, Mason DH. Controlled, multidose, pharmacokinetic evaluation of two extended-release carbamazepine formulations (Carbatrol ${ }^{\circ}$ and Tegretol-XR'). I Pharm Sci. 1998;87(12):1531-1534. 5. Mahmood I, Chamberlin N. A limited sampling method for the estimation of AUC and $\mathrm{C}_{\max }$ of carbamazepine and carbamazepine epoxide following a single and multiple dose of a sustainedrelease product. Br J Clin Pharmacol. 1998;45:241-246. 6. Carbatrol package insert, Shire Richwood Inc.

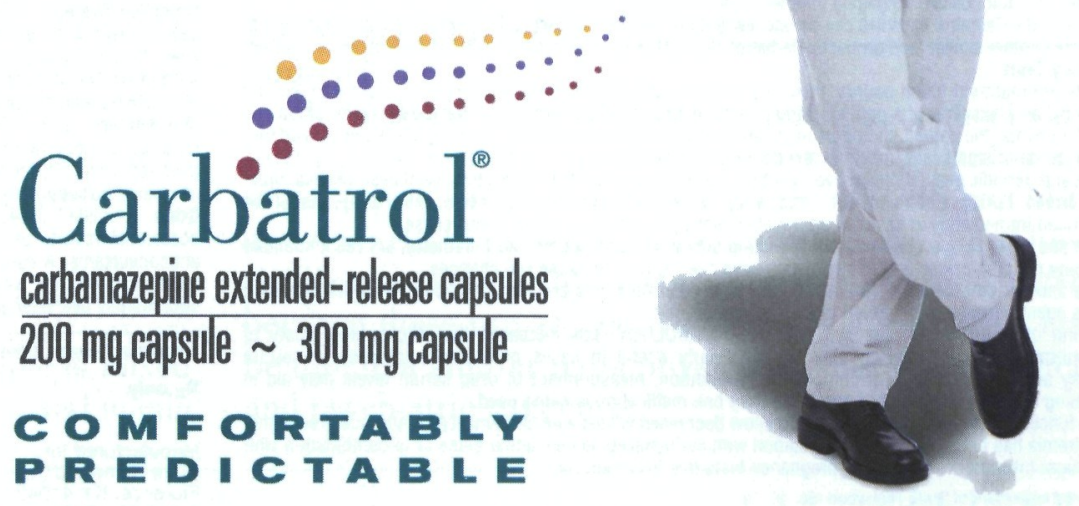




\section{CARBATROL ${ }^{\circledR}$}

\section{(1)}

$200 \mathrm{mg}$ and $300 \mathrm{mg}$

Briaf Summary Prescribing Information

\section{WARNING}

APLASTIC ANEMIA AND AGRANULOCYTOSIS HAVE BEEN REPORTED IN ASSOCIATION WITH THE USE OF CAABAMAZEPINE DATA FROM A POPULATION-BASED CASE-CONTROL STUDY DEMONSTRATE THAT THE RISK OF DEVELOPING THESE REACTIONS IS 5-8 TIMES GREATER THAN IN THE GENERAL POPULATION. HOWEVER, THE OVERALL RISK OF THESE REACTIONS N THE UNTREATED GENERAL POPULATION IS LOW. APPROXIMATELY SIX PATIENTS PER ONE MILLION POPULATION PER YEAR FOR AG TWO PATIENTS PER ONE MILLINN POPULATION PER YEAR FOR APLASTIC ANEMIA.
ALTHOUGH REPORTS OF TRANSIENT OR PERSISTENT DECREASED PLATELET OR WHITE BLOOD CEL COUNTS ARE NOT UNCOMMON IN ASSOCIATION WITH THE USE OF CARBAMAZEPINE, DATA ARE NOT AVAILABLE TO ESTIMATE ACCURATELY THEIR INCIDENCE OR OUTCOME. HOWEVER, THE VAST MAJORITY
OF THE CASES OF LEUKOPENAA HAVE NOT PROGRESSED TO THE MORE SERIOUS CONDITIONS OF OF THE CASES OF LEUKOPENIA HAVE NOT APLASTIC ANEMIA OR AGRANULOCYTOSIS. MAJURITY OF MINOR HEMATOLOGIC GHANGES OBSERVED IN MONITORING OF PATIENTS ON CAARAMAZEPINE ARE UNLLKEYY TO SIGNAL THE OCCURRENCE OF EITHER ABNORMALITY. NONETHELESS, COMPLETE PRETREATMENT HEMATOLOGICAL TESTING SHOULD BE OBTAINED AS A BASELINE. IF A COUNTS, THE PATIENT SHOULD BE MONITORED CLOSERY DISCONTINUATION OF THE DRUG SHOULD BE
CONSIDERED IF ANY EVIDENCE OF SIGNIFCANT BONE MARROW DEPRESSION DEVELOPS.

Belore preserlbing Carbatrol, the physlclan should be thoroughly famlllar with the details of the full prescribing Information, particularly regerding use with other drugs, especially those which aceentuale toxicily potential. INDICATIONS AMD USAGE

Carbatrol" is indicated for use as an anticonvulsant drug. Evidence supporting efficacy of carbamazepine as an anticonvulsant was derived from active drug-controlled studies that enrolled patients with the following seizure types:

1. Partial selzures with complex symptomatology (psychomotor, temporal lobe). Patients with these

seizures appear to show greater improvements than those with other types.

2. Generalized tonic-clonic seizures (grand mal).

3. Mixed seizure patterns which include the above, or other partial or generalized seizures. Absence seizures (petit mal) do not appear to be controlled by carbamazepine (see PRECAUTIONS, General). Trigem Inal Neuralgis

Carbatrol is indicated in the treatment of the pain associated with true trigeminal neuralgia. Beneficial results have also been reported in glossopharyngeal neuralgia. This drug is not a simple analgesic and should not be used for the relief of trivlal aches or pains.

\section{CONTRAINDICATIONS}

Carbamazepine should not be used in patients with a history of previous bone marrow depression, hypersensitivity to the drug. or known sensitivity to any of the tricyclic compounds, such as amitriptyline desipramine, imipramine, protriptylline and nortriptyline. Likewise, on theoretical grounds its use with
monoamine oxidase inhibitors is not rzcommended. Before administration of carbamazepine, MAO inhibitors monoamine oxidase Inhibitors is not recommended. Before administration of carbamazepine,
should be discontinued for a minimum of 14 days, or longer if the clinical situation permits.

\section{WARMINGS}

\section{Usage In Prepnancy}

Epidemiological data sugoest that there may be an association between the use of carbamazepine during pregnancy and congenital malformations, inciuding spina bifida. The prescribing physician will wish to weigh the benefits of therapy against the risks in treating or counseling women of childbearing potential. If this drug is used during pregnancy, or if the patient becomes pregnant while taking this drug, the patient should be apprised of the potential hazard to the fotus. Retrospective case reviews suggest that, compared with monotherapy, there may be potential hazard to the fetus. Retrospective case reviews suggest that, compared with monotherapy, there may be a higher prevalence of teratogenlc effects associated with the use of anticonvulsants in combination therapy. In humans, transplacental passage of carbamazepine is rapid (30-60 minutes), and the
in the fetal tissues, with higher levels found in liver and kidney than in brain and lung.

in the fetal tissues, with higher levels found in liver and kidney than in brain and lung.
Carbamazepine has been shown to have adverse effects in reproduction studies in rats when given orally in Carbamazepine has been shown to have adverse effects in reproduction studies in rats when given orally in dosages 10-25 times the maximum human daily dosage (MHDD) of $1200 \mathrm{mg}$ on a mg/kg basis or $1.5-4$ times the MHDD on a mg/m² basis. In rat teratology studies, 2 of 135 offspring showed kinked ribs at $250 \mathrm{mg} / \mathrm{kg}$
and 4 of 119 offspring at $650 \mathrm{mg} / \mathrm{kg}$ showed other anomalies (cleft palate, 1; talipes, 1 ; anophthalmos, 2). In reproduction studies in rats, nursing offspring demonstrated a lack of weight gain and an unkempt appearance at a maternal dosage lovel of $200 \mathrm{mg} / \mathrm{kg}$. Antiepileptic drugs should not be discontinued abruptly in patients in whom the drug is administered to prevent major seizures because of the strong possibility of precipitating status epilepticus with attendant hypoxia and threat to life. In individual cases where the severity and frequency of the seizure disorder are such that removal of medication does not pose a serious threat to the patient, discontinuation of the drug may be considered prior to and during pregnancy, although it cannot be said with any confidence that even minor seizures do not pose some hazard to the developing embryo or fetus. care in childbearing women recelving carbamazepine.

Patients with a history of adverse hematologic reaction to any drug may be particularly at risk.

Severe dermatologic reactions, Including toxic epidermal necrolysis (Lyell's syndrome) and Stevens-Johnson syndrome have been reported with carbamazepine. These reactions have been extremely rare. However, a few fatalities have been reported. Carbamazepine has shown mild anticholinergic activity; therefore, patients with increased intraocular pressure should be closely observed during therapy. Because of the relationship of the increased intraocular pressure should be closely observed during therapy. Because of the relationship of the
drug to other tricyclic compounds, the possibility of activation of a latent psychosis and, in elderly patients, of confusion or agitation should be considered.

Paneral

Before initiating therapy, a detailed history and physical examination should be made.

Carbamazepine should be used with caution in patients with a mixed seizure disorder that includes atypical absence seizures, since in these pattents carbamazepine has been associated with increased frequency of generalized convulsions (see INDICATIONS AND USAGE). Therapy should be prescribed only after critical benefit to-risk appraisal in patients with a history of cardlac, hepatlc, or renal damage; adverse hematologic reaction to other drugs; or interrupted courses of therapy with carbamazepine.

\section{Information for Pationts}

Patients should be made aware of the early toxic signs and symptoms of a potential hematologic problem, such as fever, sore throat, rash, ulcers in the mouth, easy bruising, petechial or parpuric hemorrhage, and should be advised to report to the physiclan Immediately if any such signs or symptoms appear.

Since dizziness and drowsiness may occur, patients should be cautioned about the hazards of operating machinery or automobiles or engaging in other potentially dangerous tasks.

If necessary, the Carbatrol capsules can be opened and the contents sprinkled over food, such as a teaspoon of applesauce or other similar food products. Carbatrol capsules or their contents should not be crushed or chewed. Laboratory Tests

Complete pretreatment blood counts, Including platelets and possibly reticulocytes and serum iron, should be obtained as a baseline. If a patient in the course of treatment exhibits low or decreased white blood cell be obtained as a baseline. If a patient in the course of treatment exhibits low or decreased white blood cell if any evidence of significant bone marrow depression develops.

Baseline and periodic evaluations of liver function, particularly in patients with a history of liver disease, must be performed during treatment with this drug since liver damage may occur. The drug should be discontinued immediately in cases of aggravated liver dysfunction or active liver disease.

Baseline and periodic eye examinations, including slit-lamp, funduscopy, and tonometry, are recommended since many phenothlazines and related drugs have been shown to cause eye changes.

Baseline and periodic complete urinalysis and BUN determinations are recommended for patients treated with this agent because of observed renal dysfunction.

Monitoring of blood levels (see CLINICAL PHARMACOLOGY) has increased the efficacy and safety of anticonvulsants. This monltoring may be particularly useful in cases of dramatic increase in seizure
frequency and for verlfication of compliance. In addition, measurement of drug serum levels may aid in determining the cause of toxicity when more than one medication is being used.

Thyroid tunction tests have been reported to show decreased values with carbamazepine administered alone. Hyponatremia has been reported in association with carbamazepine use, either alone or in combination with other drugs. Interference with some pregnancy tests has been reported.

"Registered trademark of Shire Richwood inc.

Pageatbiafr/ $/ 10.1017 /$ S1092852900013298 Published online by Cambridge University Press
Deaningful drug interactions have occurred with concomitant medlcations and include, but are not imited to the following:

Agents that may aftect carbamazepine plasma levels:

CYP $3 A 4$ inhibitors intibit carbamazepine metabolism and can thus. Increase plasma carbamazepine levels. Dregs that have been shown, or would be expected, to increase plasma carbamazepine levels include:

cimetidine, danazol diltiazem, macrolides, erythromycin, trolsandomycin, clarthromycin, fluoxettne, loratadine,

terfenadine, isoniazid, niacinamide, nicotinamide, propoxyphene, ketoconazole, itraconazole, verapamil, valproate. * CYP $3 A 4$ inducers can increase the rate of carbamazepine metabolism and can thus decrease plasma carbamazepine levels. Drugs that have been shown, or would be expected, to decrease plasma carbamazepine levels include:

cisplatin, doxorubicin HCL, felbamate, rifampin ", phenobarbital, ph

Carbatrol increases levels of clomipramine HCL, phenytoin and primidone.

Carbatrol induces hepatic CYP activity. Carbatrol causes, or would be expected to cause decreased levels of the following:

acetaminophen, alprazolam, clonazepam, clozapine, dicumarol, doxycycllne, ethosuximide, haloperidol, methsuximide, oral contraceptives, phensuximide, phenytoin, theophyline, valproate, wartarin.

The doses of these drugs may therefore have to be increased when carbamazepine is added to the therapeutic regimen. Concomitant administration of carbamazepine and lithium may increase the risk of neurotoxic side effects. Alterations of thyroid function have been reported in combination therapy with other anticonvulsant medications. Breakthrough bleeding has been reported among patients recelving concomitant oral contraceptives and their reliability may be adversely affectod.

Administration of carbamazepine to Sprague-Dawley rats for two years in the diet at doses of 25,75 , and 250 $\mathrm{mg} / \mathrm{kg} /$ day (low dose approximately 0.2 times the maximum human daily dose of $1200 \mathrm{mg}$ on a mg/m² basis), resulted in a dose-related increase in the incide

interstitial cell adenomas in the testes of males. mammalian mutagenicity studies using carbamazepine produced negative results. The significance of these findings relative to the use of carbamazepine in humans is, at present, unknown.

Usage in Pregnaney

Pregnancy Category D (See WARNINGS)

Labor and Dellvery

The effect of carbamazepine on human labor and delivery is unknown.

\section{Nursing Mothers}

Carbamazepine and its epoxide metabolite are transferred to breast milk and during lactation. The concentrations of carbamazepine and its epoxide metabolite are approximately $50 \%$ of the maternal plasma concentration. Because of the potential for serious adverse reactlons in nursing infarits from carbamazepine, a decision should be made whether to

Pedlatric Uso

Substantial evidence of carbamazepine effectiveness for use in the management of chlldren with epilepsy (see INDICATIONS for specific seizure types) is derived from clinical investigations performed in adults and from studies in several in vitro systems which support the conclusion that (1) the pathogenic mechanisms underlying seizure propagation are essentially identical in adults and children, and (2) the mechanism of action of carbamazepine in treating seizures is essentially identicas in adults and chlldren. Taken as a whole, this of carbamazepine in treating seizures is essentially identical in adults and children. Taken as a whole, this plasma (i.e. 4-12 $\mu \mathrm{g} / \mathrm{mL}$ ) is the same in children and adults. The evidence assembled was primarily obtained plasma (i.e., $4-12 \mu \mathrm{g} / \mathrm{mL}$ ) is the same in children and adults. The evidence assembled was primarily obtained
from short-term use of carbamazepine. The safety of carbamazepine in children has been systematically studied up to 6 months. No longer term data from clinical trials is available.

Gariatric Use

No systematic studies in geriatric patients have been conducted.

Adverse Reactlons

General: If adverse reactions are of such severity that the drug must be discontinued, the physician must be aware that abrupt discontinuation of any anticonvulsant drug in a responsive patient with epilepsy may lead to seizures or even status epilepticus with its life-threatening hazards.

The most severe adverse reactions previously observed with carbamazepine were reported in the hemopoietic system (see BOX WARNING), the skin, and the cardiovascular system.

The most frequently observed adverse reactions, particularly during the initlal phases of therapy, are dizziness, drowsiness, unsteadiness, nausea, and vomlting. To minimize the possibility of such reactions, therapy should be initiated at the lowest dosage recommended.

The following additional adverse reactions were prevlously reported with carbamazepine:

Hemopoletie System: Aplastic anemia, agranulocytosis, pancytopenia, bone marrow depression, thrombocytopenia, leukopenia, leukocytosis, eosinophilia, acute intermittent porphyria.

Skin: Pruritic and erythematous rashes, urticaria, toxic epldermal necrolysis (Lyell's syndrome) (seo WARNINGS), Stevens-Johnson syndrome (see WARNINGS), photosensitivity reactions, alterations in skin pigmentation, extoliative dermatitis, erythema multiforme and nodosum, purpura, agoravation of disseminated lupus erythematosus, aiopecia, and diaphoresis. In certain cases, discontinuation of therap

Isolated cases of hirsutism have been reported, but a causal relationship is not clear. and collapse, aggravation of coronary artery disease, arrhythmias and AV block, thrombophlebitis, thromboembolism, and adenopathy or lymphadenopathy. Some of these cardiovascular complications have resulted in fatalities. Myocardial infarction has been associated with other tricycllc compounds.

resulted in fatallties. Myocardial infarction has been associated with other tricycllc compounds.

Liver: Abnormalities in liver function tests, cholestatic and hepatocellular jaundice, hepatitis. Resplratory System: Puimonary hypersensitivity characterized by fever, dyspnea, pneumonitis, or pneumonia. renal fallure, and impotence. Albuminuria, alycosuria, elevated BUN, and microscopic deposits in the urine have also been reported. Testicular atrophy occurred in rats receiving carbamazepine orally from 4-52 weeks at dosage levels of $50-400 \mathrm{mg} / \mathrm{kg} / \mathrm{day}$. Additionally, rats receiving carbamazepine in the dlet for 2 years at dosage levels of 25,75 , and $250 \mathrm{mg} / \mathrm{kg} /$ day had a dose-related incidence of testicular atrophy and aspermatogenesis. In dogs, it produced a brownish discoloration, presumabiy a metabolite, in the urinary bladder at dosage levels of $50 \mathrm{mg} / \mathrm{kg} /$ day and higher. Relevance of these findings to humans is unknown.

Nervous sysiem: Dizziness, drowsiness, disturbances of coordination, confusion, headache, fatique, blurred vision, visual hallucinations, transient diplopia, oculomotor disturbances, nystagmus, speech disturbances, abnormal involuntary movements, peripheral neuritis and paresthesias, depression with agitation, talkativeness, tinnitus, and hyperacusis.

There have been reports of associated paralysis and other symptoms of cerebral arterial insufficiency, but the exact There have been reports of associated paralysis and other symptoms

Isolated cases of neuroleptic malignant syndrome have been reported with concomitant use of psychotropic drugs. Olgestive System: Nausea, vomiting, gastric distress and abdominal pain, diarrhea, constipation, anorexia, and dryness of the mouth and pharynx, including glossitis and stomatitis.

Eyes: Scattered punctate cortical lens opacities, as well as conjunctivitis, have been reported. Although a direct causal relationship has not been established, many phenothiazines and related drugs have been shown to cause eye changes. Musculoskeletal System: Aching joints and muscles, and leg cramps.

Metaholism: Fever and chitls, inappropriate antidiuretic hormone (ADH) secretion syndrome has been reported. Cases of frank water intoxication, with decreased serum sodium (hyponatremia) and confusion have of plasma calcium have been reported.

Other: isolated cases of a lupus erythematosus-like syndrome have been reported. There have been occasional reports of elevated levels of cholesterol, HDL cholesterol, and triglycerides in patients taking anticonvulsants. A case of aseptic meningitis, accompanied by myoclonus and peripheral eosinophilia, has been reported in a patient taking carbamazepine in combination with other medications. The patient was successfully dechallenged, and the meningitis reappeared upon rechallenge with carbamazepine.

*increased levels of the active 10, 11-epoxide

$\mathbf{R}_{\mathbf{x}}$ only.

700421 (rev. 8/98)

Manufactured for:

Shire Richwood Inc.

1-800-536-7878 


\section{AN INTEGRATED HYPOTHESIS}

\section{page 26}

"It is clear that no single neurochemical system has been shown to be responsible for either catatonia or NMS. The universal field hypothesis declares that it is the interaction of these systems that is responsible for catatonia and NMS. Furthermore, the hypothesis states that there must be some predisposition in the individual patient at the neurochemical level for the development of catatonia and NMS. We might therefore conclude that at the neurochemical level, these patients already have low $\mathrm{GABA}_{\mathrm{A}}$ activity, high $5-\mathrm{HT}_{1 \mathrm{~A}}$ receptor activity, low activity at $\mathrm{D}_{2}$ dopamine systems, or alterations at the NMDA receptor in the glutamate system. The universal field hypothesis is based upon models proposed for catatonia by Lauterbach. He notes that each of these systems- $\mathrm{D}_{2}, \mathrm{GABA}_{\mathrm{A}}, 5-\mathrm{HT}_{1 \mathrm{~A}}$, and NMDAhas dynamic influence over circuits involved in catatonia so that perturbation of any one of these receptors can push the balance of systems toward or away from catatonia. In NMS, reduction of dopamine activity at the $D_{2}$ receptor by $D_{2}$ antagonists may be the primary pathogenesis of the syndrome in which $\mathrm{GABA}_{A}, 5-\mathrm{HT}_{1 \mathrm{~A}}$, and NMDA play a necessary, secondary role."

\section{THE UNDERLYING NETWORK}

\section{page 34}

"Catatonic patients are well able to initiate movements, but they are apparently unable to terminate the movement once initiated in an appropriate way. In contrast to initiation neural networks, the study of underlying termination of movements has been neglected in the research to date. In healthy individuals, termination of movements is believed to involve the right posterior parietal cortex, because the registration and on-line monitoring of the respective spatial position of the movement may be of central importance for an appropriate termination. Since findings in imaging and neuropsychology indicate a relationship between deficits in visual-constructive functions and decreased $\mathrm{rCBF}$ in the right posterior parietal cortex, alterations in the right posterior parietal cortical function may account for the deficit in termination of movements in catatonia that result in the motor symptom of posturing. This assumption is further supported by our findings in late MRCPs as well as fMRI, reflecting alterations in termination rather than initiation. If registration and on-line monitoring of the spatial position of movements (as related to right posterior parietal cortical function) are deficient in catatonia, this should lead to an unawareness of the respective spatial position. This is indeed the case since catatonic patients (unlike Parkinson's disease patients) suffer from anosognosia of posturing."

\section{THE CATATONIA-MANIA MIX page 48}

"The symptom distribution in the total sample of mixed manics suggests that catatonic symptoms in mixed mania are mainly restricted to those associated with motor arousal or inhibition (eg, iterations, verbigerations, jerky movements, mutism), whereas symptoms of catalepsy (eg, waxy flexibility, posturing) and with the exception of exaggerated responsiveness, symptoms of disturbance of volition (eg, gegenhalten, automatic obedience) do not occur to a significant degree. In fact, based on the severity ratings of mutism, motor excitement, and verbigerations alone, catatonic mixed manics were classified into those who would need ACU admission and those who would not. Verbigerations and other symptoms of speech disturbance are considered one of the hallmarks of catatonia and are reported to be neglected in modern catatonia research. The authors' findings confirm this observation."

\section{HASTENING RECOVERY}

\section{page 54}

"If benzodiazepines prove beneficial in hastening recovery in NMS, available models of action may explain the mechanisms. Benzodiazepines increase dopamine activity by indirect actions involving $\gamma$-aminobutyric acid systems in nuclei of the basal ganglia, including both the striatum and substantia nigra. Dopamine deficiency or blockade has been hypothesized in the pathogenesis of NMS, and benzodiazepines are known to antagonize some adverse motor effects of dopamine-blocking neuroleptic drugs. A weakness of the dopamine hypothesis in NMS is its failure to account for the rarity of this syndrome among large numbers of patients prescribed neuroleptics, and the observation that NMS may not recur following neuroleptic reexposure."

\section{A UNITARY PATHOLOGICAL DISORDER page 58}

"The authors hypothesize that the hyperdopaminergic state allegedly linked to schizophrenia may in fact protect schizophrenic patients from the marked neurolepticinduced dopamine receptor blockade that possibly underlies the development of NMS. It would follow, therefore, that if NMS and catatonia share a similar pathophysiology (namely, that both represent a hypodopaminergic state), then this may also account for the infrequent occurrence of the catatonic syndrome in schizophrenic patients."

\section{DIFFERENTIATING SIGNS? \\ page 66}

"If catatonic signs are less prominent in medical catatonias, one would expect differences in the total rating scale scores, but total scores from the BFCRS and MRS are remarkably similar between these groups. These findings suggest that catatonic signs do not differ between these two groups. This similar presentation may be due to a similar pathophysiology shared by medical and psychiatric catatonias." 
References: 1. Pelham WE, Aronoff HR, Midlam JK, et al. A comparison of Ritalin and Adderall: efficacy and time-course in children with attention-deficit/hyperactivity disorder Pediatrics [serial online]. 1999;103:e43. Available at: http://www.pediatrics.org/. 2. Pliszka S, Browne RG, Wynne SK, et al. Comparing Adderall and methylphenidate in ADHD. J Am Acad Child Adolesc Psychiatry. 2000;39(5):619-626. 3. Pelham WE, Gnagy EM, Chronis MA, et al. A comparison of morning-only and morning/late afternoon Adderall to morning-only, twice-daily, and three times-daily methylphenidate in children with attention-deficit/hyperactivity disorder. Pediatrics. 1999;104(6):1300-1311. 4. IMS, National Prescription Audit, January through December 1999. 5. Data on file, Shire Richwood Inc.

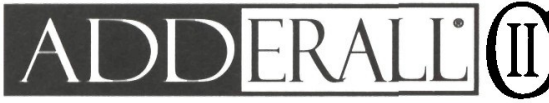

ADDERALL ${ }^{\circledR}$ TABLETS

AMPHETAMINES HAVE A HIGH POTENTIAL FOR ABUSE ADMINISTRATION OF AMPHETAMINES FOR PROLONGED PERIODS OF TIME MAY LEAD TO DRUG DEPENDENCE AND MUST BE AVOIDED. PARTICULAR ATTENTION SHOULD BE PAID TO THE POSSIBILITY OF SUBJECTS OBTAINING AMPHETAMINES FOR NONTHERAPEUTIC USE OR DISTRIBUTION TO OTHERS, AND THE DRUGS SHOULD BE PRESCRIBED OR DISPENSED SPARINGLY.

INDICATIONS: Attention Deficlt Dlsorder with Hyperactivlty: ADDERALL is indicated as an integral part of a total treatment program which typically includes other remedial measures (psychological, educational, social) for a stabilizing effect in children with behavioral syndrome characterized by the following group of developmentally inappropriate symptoms: moderate to severe distractibility, short attention span, hyperactivity, emotional lablity, and impulsivity. The diagnosis of this syndrome should not be made with finality when these symptoms are only of comparatively recent origin. Nonlocalizing (soft) neurological signs, learning disability and abnormal EEG may or may not be present, and a diagnosis of central nervous system dysfunction may or may not be warranted. In Narcolopsy: CONTRAINDICATIONS: Advanced arteriosclerosis, symptomatic cardiovascular disease, moderate to severe hypertension, hyperthyroidism, known hypersensitivity or idiosyncrasy to the sympathomimetic amines, glaucoma. Agitated states. Patients with a history of drug abuse. During or within 14 days following the administration of monoamine oxidase inhibitors (hypertensive crises may result). WARNINGS: Clinical experience suggests that in psychotic children, administration of amphetamine may exacerbate symptoms of behavior disturbance and thought disorder. Data are inadequate to determine whether chronic administration of amphetamine may be associated with growth inhibition; therefore, growth should be monitored during treatment. Usage in Nursing Mothers: Amphetamines are excreted in human milk. Mothers taking amphetamines should be advised to refrain from nursing. PRECAUTIONS: General: Caution is to be exercised in prescribing amphetamines for patients with even mild hypertension. The least amount feasible should be prescribed or dispensed at one time in order to minimize the possibility of overdosage. Information for Patients: Amphetamines may impair the ability of the patient to engage in potentially hazardous activities such as operating machinery or vehicles; the patient should therefore be cautioned accordingly. Drug Interactlons: Acidifying agents Gastrointestinal acidifying agents (guanethidine, reserpine, glutamic acid $\mathrm{HCl}$, ascorbic acid, fruit juices, etc.) lower absorption of amphetamines. Urinary acidifying agents (ammonium chloride, sodium acid phosphate, etc.) Increase the concentration of the ionized species of the amphetamine molecule, thereby increasing urinary excretion. Both groups of agents lower blood levels and efficacy of amphetamines. Adrenergic blockers - Adrenergic blockers are inhibited by amphetamines. Alkalinizing agents - Gastrointestinal alkalinizing agents (sodium bicarbonate, etc.) increase absorption of amphetamines. Urinary alkalinizing agents (acetazolamide, some thiazides) increase the concentration of the nonionized species of the amphetamine molecule, thereby decreasing urinary excretion. Both groups of agents increase blood levels and therefore potentiate the actions of amphetamines. Antidepressants, tricyclic - Amphetamines may enhance the activity of tricyclic or sympathomimetic agents; $d$-amphetamine with desipramine or protriptyline and possibly other tricyclics cause striking and sustained increases in the concentration of damphetamine in the brain; cardiovascular effects can be potentiated. MAO inhibitors - MAOI antidepressants, as well as a metabolite of furazolidone, slow amphetamine metabolism. This slowing potentiates amphetamines, increasing their effect on the release of norepinephrine and other monoamines from adrenergic nerve endings: this can cause headaches and other signs of hypertensive crisis. A variely of neurological toxic effects and malignant hyperpyrexia can occur, sometimes with fatal results. Antihistamines Amphetamines may counteract the sedative effect of antihistamines. Antihypertensives Amphetamines may antagonize the hypotensive effects of antihypertensives. Chlorpromazine - Chlorpromazine blocks dopamine and norepinephrine reuptake, thus inhibiting the central stimulant effects of amphetamines, and can be used to treat amphetamine poisoning. Ethosuximide - Amphetamines may delay intestinal absorption of ethosuximide. Haloperidol - Haloperidol blocks dopamine and norepinephrine reuptake, thus inhibiting the central stimulant effects of amphetamines. Lithium carbonate - The anorectic and stimulatory effects of amphetamines may be inhibited by lithium carbonate. Meperidine Amphetamines potentiate the analgesic effect of meperidine. Methenamine therapy Urinany excretion of amphetamines is increased, and efficacy is reduced, by acidifying agents used in methenamine therapy. Norepinephrine - Amphetamines enhance the adrenergic effect of norepinephrine. Phenobarbital - Amphetamines may delay intestinal absorption of phenobarbital; co-administration of phenobarbital may produce a synergistic anticonvulsant action. Phenytoin - Amphetamines may delay intestinal absorption of phenytoin; co-administration of phenytoin may produce a synergistic anticonvulsant action. Propoxyphene - In cases of propoxyphene overdosage, amphetamine CNS stimulation is potentialed and fatal convulsions can occur. Veratrum alkaloids - Amphetamines inhibit the hypotensive effect of veratrum alkaloids. Drug/Laboratory Test Interactions: • Amphetamines can cause a significant elevation in plasma corticosteroid levels. This increase is greatest in the evening. Amphetamines may interfere with urinary steroid determinations. Carclnogenesla/Mutagenesls: Mutagenicity studies and long-term studies in animals to determine the carcinogenic potential of amphetamine, have not been performed. Pregnancy - Teratogenlc Effects: Pregnancy Category C. Amphetamine has been shown to have embryotoxic and teratogenic effects when administered to $A / J a x$ mice and C57BL mice in doses approximately 41 times the maximum human dose. Embryotoxic effects were not seen in New Zealand white rabbits given the drug in doses 7 times the human dose nor in rats given 12.5 times the maximum human dose. While there are no
$5 \mathrm{mg}, 10 \mathrm{mg}, 20 \mathrm{mg}$ a $30 \mathrm{mg}$ TABLETS (Mixed Salts of a Single-Entity Amphetamine Product)
Dextroamphetamine Sullate Amphetamine Sulfate
Dextroamphetamine Saccharate Amphetamine Aspartate

\section{(11.BRIEF SUMmary}

adequate and well-controlled studies in pregnant women, there has been one report of severe congenital bony deformity, tracheoesophageal fistula, and anal atresia (vater association) in a baby born to a woman who took dextroamphetamine sulfate with lovastatin during the first trimester of pregnancy. Amphetamines should be used during pregnancy only if the potential benefit justifies the potential risk to the fetus. Nonteralogenic Effects: Infants born to mothers dependent on amphetamines have an increased risk of premature delivery and low birth weight. Also, these infants may experience symptoms of withdrawa as demonstrated by dysphoria, including agitation, and significant lassitude. Pedlatric Use: Long-term effects of amphetamines in children have not been well established. Amphetamines are not recommended for use in children under 3 years of age with Attention Deficit Disorder with Hyperactivity described under INDICATIONS AND USAGE. Amphetamines have been reported to exacerbate motor and phonic tics and Tourette's syndrome. Therefore, clinical evaluation for tics and Tourette's syndrome in children and their families should precede use of stimulant medications. Drug treatment is not indicated in all cases of Attention Deficit Disorder with Hyperactivity and should be considered only in light of the complete history and evaluation of the child. The decision to prescribe amphetamines should depend on the physician's assessment of the chronicity and severity of the child's symptoms and their appropriateness for his/her age. Prescription should not depend solely on the presence of one or more of the behavioral characteristics. When these symptoms are associated with acute stress reactions, treatment with amphetamines is usually not indicated. ADVERSE REACTIONS: Cardlovascular: Palpitations, tachycardia, elevation of blood pressure. There have been isolated reports of cardiomyopathy associated with chronic amphetamine use. Central Nervous System: Psychotic episodes at recommended doses (rare), overstimulation, restlessness, dizziness, insomnia, euphoria, dyskinesia, dysphoria, tremor, headache, exacertation of motor and phonic tics and Tourette's syndrome. Gastrointestinal: Dryness of the mouth, unpleasant taste, diarrhea, constipation, other gastrointestinal disturbances. Anorexia and weight loss may occur as undesirable effects when amphetamines are used for other than the anorectic effect. Allergic: Urticaria. Endocrine: Impotence, changes in libido. DRUG ABUSE AND DEPENDENCE: Dextroamphetamine sulfate is a Schedule II controlled substance. Amphetamines have been extensively abused. Tolerance, extreme psychological dependence, and severe socia disability have occurred. There are reports of patients who have increased the dosage to many times that recommended. Abrupt cessation following prolonged high dosage administration results in extreme fatigue and mental depression; changes are also noted on the sleep EEG. Manifestations of chronic intoxication with amphetamines include severe dermatoses, marked insomnia, irritability, hyperactivity, and personality changes. The most severe manifestation of chronic intoxication is psychosis, often clinically indistinguishable from schizophrenia. This is rare with oral amphetamines. OVERDOSAGE: Individual patient response to amphetamines varies widely. While toxic symptoms occasionally occur as an idiosyncrasy at doses as low as $2 \mathrm{mg}$, they are rare with doses of less than $15 \mathrm{mg} ; 30 \mathrm{mg}$ can produce severe reactions, yet doses of 400 to $500 \mathrm{mg}$ are not necessarily latal. In rats the oral $L_{50}$ of dextroamphetamine sulfate is $96.8 \mathrm{mg} / \mathrm{kg}$. Symptoms: Manifestations of acute overdosage with amphetamines include restlessness, tremor, hyperreflexia, rapid respiration, confusion, assaultiveness, hallucinations, panic states, hyperpyrexia and rhabdomyolysis. Fatigue and depression usually follow the central stimulation. Cardiovascular effects include arrhythmias, hypertension or hypotension and circulatory collapse. Gastrointestinal symptoms include nausea, vomiting, diarrhea, and abdominal cramps. Fatal poisoning is usually preceded by convulsions and coma. Treatment: Consult with a Certified Poison Control Center for up to date guidance and advice. Management of acute amphetamine intoxication is largely symptomatic and includes gastric lavage administration of activated charcoal, administration of a cathartic and sedation. Experience with hemodialysis or peritoneal dialysis is inadequate to permit recommendation in this regard. Acidification of the urine increases amphetamine excretion, but is believed to increase risk of acute renal failure if myoglobinuria is present. If acute, severe hypertension complicates amphetamine overdosage, administration of intravenous phentolamine (Regitine ${ }^{*}$, Novartis) has been suggested. However, a gradual drop in blood pressure will usually result when sufficient sedation has been achieved. Chlorpromazine antagonizes the central stimulant effects of amphetamines and can be used to treat amphetamine intoxication. DOSAGE AND ADMINISTRATION: Regardless of indication, amphetamines should be administered at the lowest effective dosage and dosage should be individually adjusted. Late evening doses should be avoided because of the resulting insomnia. Attention Deficit Disorder with Hyperactlvity: Not recommended for children under 3 years of age. In children from 3 to 5 years of age, start with $2.5 \mathrm{mg}$ daily; daily dosage may be raised in increments of $2.5 \mathrm{mg}$ at weekly intervals until optimal response is obtained. In children 6 years of age and older, start with $5 \mathrm{mg}$ once or twice daily; daily dosage may be raised in increments of $5 \mathrm{mg}$ at weekly intervals until optimal response is obtained. Only in rare cases will it be necessary to exceed a total of $40 \mathrm{mg}$ per day. Give first dose on awakening; additional doses (1 or 2) at intervals of 4 to 6 hours. Where possible, drug administration should be interrupted occasionally to determine if there is a recurrence of behavioral symptoms sutficient to require continued therapy. Narcolepsy: Usual dose $5 \mathrm{mg}$ to $60 \mathrm{mg}$ per day in divided doses. depending on the individual patient response. Narcolepsy seldom occurs in children under 12 years of age; however, when it does, dextroamphetamine sulfate may be used. The suggested initial dose for patients aged 6-12 is $5 \mathrm{mg}$ daily; daily dose may be raised in increments of 5 $\mathrm{mg}$ at weekly intervals until optimal response is obtained. In patients 12 years of age and older, start with $10 \mathrm{mg}$ daily; daily dosage may be raised in increments of $10 \mathrm{mg}$ at weekly intervals until optimal response is obtained. If bothersome adverse reactions appear (e.g. insomnia or anorexia), dosage should be reduced. Give first dose on awakening; additional doses ( 1 or 2 ) at intervals of 4 to 6 hours. Rx only. 


\section{If methylphenidate (MPH) seems to be "working fine"...}

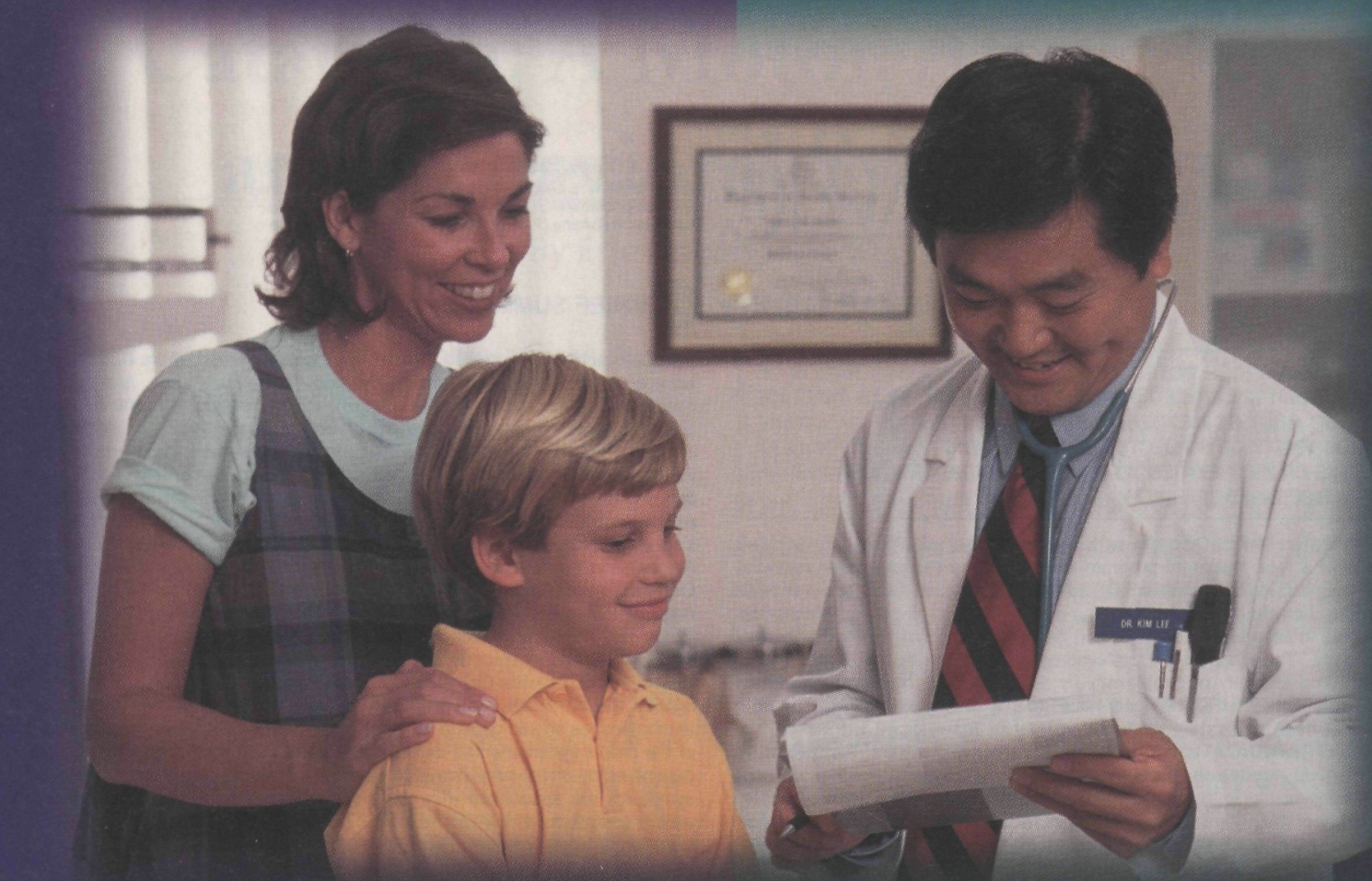

\section{Why make the switch to ADDERALL ${ }^{\oplus}$ ?}

On average, ADDERALL is more effective than Ritalin ${ }^{\oplus}(p<0.001)^{1}$

- ADDERALL was favored 3 to 1 over Ritalin by clinical staff for continued medication ${ }^{1}$

- Ritalin patients were rated more deviant than ADDERALL, particularly on lower doses ${ }^{1}$

- ADDERALL scored better than MPH on Clinical Global Impression (CGI) improvement $(p<0.05)^{2}$

- There were significantly more responders in the ADDERALL group than the MPH group $(p<0.01)^{2}$

- ADDERALL showed better scores than MPH for both inattention and hyperactivity $(p<0.05)^{2}$

- Clinical staff clearly preferred ADDERALL over MPH for continuation of treatment ${ }^{3}$

- ADDERALL is dispensed for more ADHD patients than Ritalin ${ }^{4}$

ADDERALL is safe-low incidence of spontaneously reported adverse events ${ }^{5}$

ADDERALL is generally well tolerated - adverse reactions have seldom been reported (most frequently reported adverse reactions include anorexia, insomnia, stomach pain, headache, irritability, and weight loss).

As with most psychostimulants indicated for ADHD, the possibility of growth suppression and the potential for precipitating motor tics and Tourette's syndrome exist with ADDERALL treatment and, in rare cases, exacerbations of psychosis have been reported. Since amphetamines may have a high potential for abuse, ADDERALL should only be prescribed as part of an overall multimodal treatment program for ADHD with close physician supervision.

ADDERALL is a registered trademark of Shire US Inc.

Ritalin is a registered trademark of Novartis Pharmaceuticals Corp.
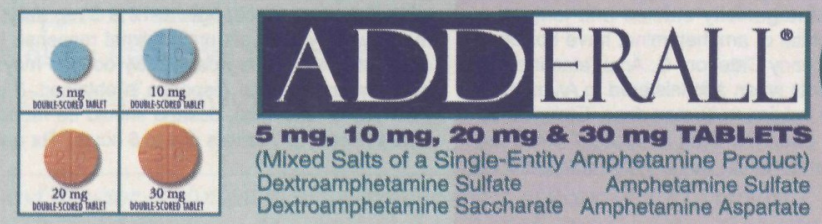

ADD528-JA
Please see references and brief prescribing information on adjacent page.

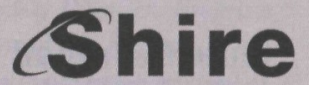




\section{Table of Contents}

Feature Articles

25 Introduction-Mechanisms and Presentations of Catatonia

By Brendan T. Carroll, MD

26 The Universal Field Hypothesis of Catatonia and

Neuroleptic Malignant Syndrome

By Brendan T. Carroll, MD

34 Brain Imaging in Catatonia:

Current Findings and a Pathophysiologic Model

By Georg Northoff, MD, PhD

48 Catatonia in Affective Disorder:

New Findings and a Review of the Literature

By Stephanie Krüger, MD, and Peter Bräunig, MD

54 Is Lorazepam a Treatment for Neuroleptic

Malignant Syndrome?

By Andrew Francis, MD, PhD, Sanjay Chandragiri, MD,

Syed Rizvi, MD, Monika Koch, MD, and Georgios Petrides, MD

58 An Analysis of 17 Catatonic Patients Diagnosed With

Neuroleptic Malignant Syndrome

By Denise A. C. White, MBChB, MMed, FCPsych, and Ashley H. Robins, MD, MBChB, MRCPsych

66 Catatonic Signs in Medical and Psychiatric Catatonias

By Brendan T. Carroll, MD, John C. Kennedy, MD, and Harold W. Goforth, MD

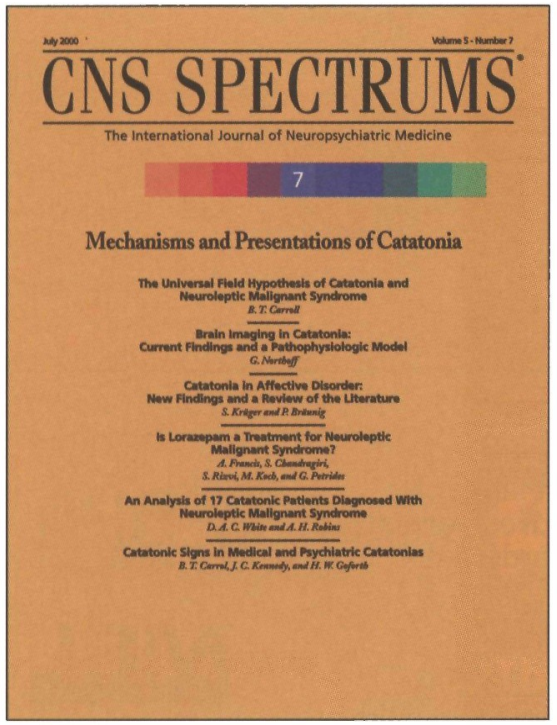

CNS SPECTRUMS

The International Journal of

Neuropsychiatric Medicine

Volume 5 - Number 7 July $\mathbf{2 0 0 0}$

CNS Spectrums is a peer review journal and is indexed in EMBASE/Excerpta Medica, DIALOG, SilverPlatter, OVID, and Lexis-Nexis. CNS Spectrums is endorsed by, and is the official journal of, the International Neuropsychiatric Association, with members in 30 countries.

\section{CNS Spectrums}

(ISSN 1092-8529)

is published monthly by

MBL Communications, 665 Broadway, Suite 805, New York, NY 10012-2302.

Periodicals postage paid at New York, NY, and at additional mailing offices.

One year subscription rates: domestic \$90;

foreign \$145;

in-training $\$ 50$.

For subscriptions:

Fax: 212-328-0600.

E-mail:

jpl@medworksmedia.com

Postmaster:

Send address changes to

CNS Spectrums

do PPS Medical Marketing Group

264 Passaic Ave.

Fairview, NJ 07004-2595 


\section{$\overline{\text { CNS SPECTRUMS }^{\circ}}$}

The International Journal of

Neuropsychiatric Medicine

Volume 5 - Number 7 July 2000
Table of Contents

Departments/MonthIy Columns

POINT \& COMMENTARY

10 Catatonia: A Motor, Affective, and Behavioral Syndrome By Eric Hollander, MD

FIRST PERSON

17 Cuba II: A Land Stuck in Time

By Charles B. Nemeroff, MD, PhD

\section{CNS NEWS}

18 Briefs from the Fields of Neurology \& Neuropsychiatry

\section{GRAND ROUNDS}

70 Catatonia due to Thalamic Degeneration: A Case Report By Brendan T. Carroll, MD, and Harold W. Goforth, MD

\section{CONTINUING MEDICAL EDUCATION}

75 This continuing medical education series gives the reader the opportunity to test his/her understanding and recall of clinical material presented in this issue. Approved for 3.0 credit hours in Category 1.

\section{INDICES}

78 By subject and author

For editorial and advertising inquiries, please fax 212-328-0600.

Opinions and views expressed by authors are their own and do not necessarily reflect the views of the publisher, MBL Communications, or the editorial advisory board. Advertisements in CNS Spectrums are accepted on the basis of adherence to ethical medical standards, but acceptance does not imply endorsement by CNS Spectrums, or the publisher.

CNS Spectrums $\otimes$ is a registered trademark of CNS Spectrums, LLC, New York, NY. CNS News'm is a trademark of MBL Communications, Inc., New York, NY.

Permission to reproduce articles in whole or part must be obtained in writing from the publisher.

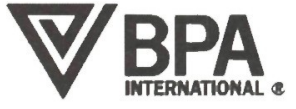




\section{Custom-tallored}

dosing

In two 6- to 8-week placebo-controlled clinical trials, spontaneously reported, treatment-emergent adverse events with an incidence of $5 \%$ or greater in at least one of the RISPERDAL groups and at least twice that of placebo were: anxiety, somnolence, extrapyramidal symptoms, dizziness, constipation, nausea, dyspepsia, rhinitis, rash, and tachycardia.

\section{Fitted to everyone}

EPS with RISPERDAL, while dose-dependent, are comparable to placebo at doses $\leq 6 \mathrm{mg} /$ day and differ significantly from placebo at doses $>6 \mathrm{mg} /$ day. Prescribing should be consistent with the need to minimize the risk of tardive dyskinesia; if its signs and symptoms appear, discontinuation of RISPERDAL should be considered.

Orthostatic hypotension was reported infrequently $(<1 \%)$ in clinical trials; its risk may be minimized by following the recommended RISPERDAL dose titration regimen.
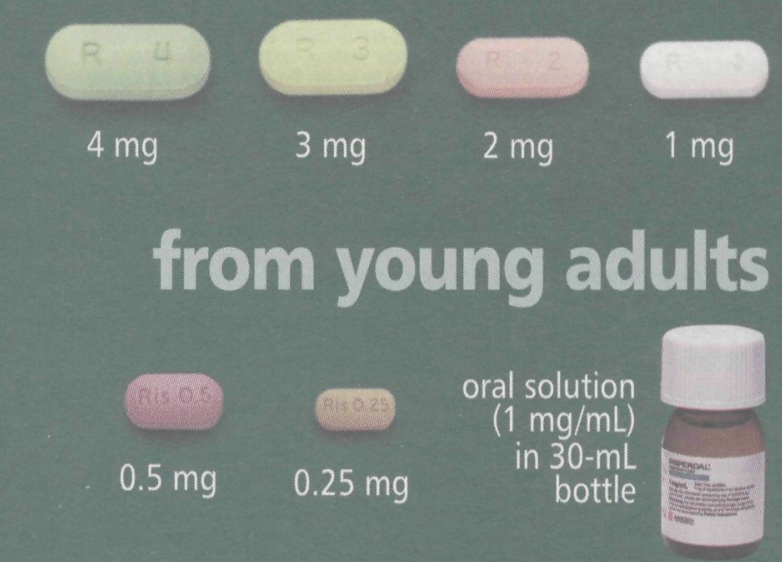

to special populations

*Patients who are elderly or who are renally or hepatically impaired.

\section{Reference:}

1. IMS America, 12/99.

Please see brief summary of Prescribing Information on adjacent page.

(C) Janssen Pharmaceutica Products, L.P. 2000

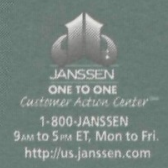

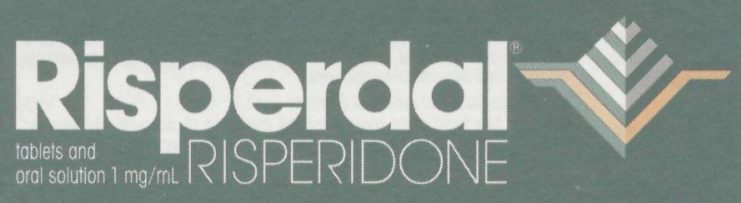

The \#1 prescribed antipsychotic'
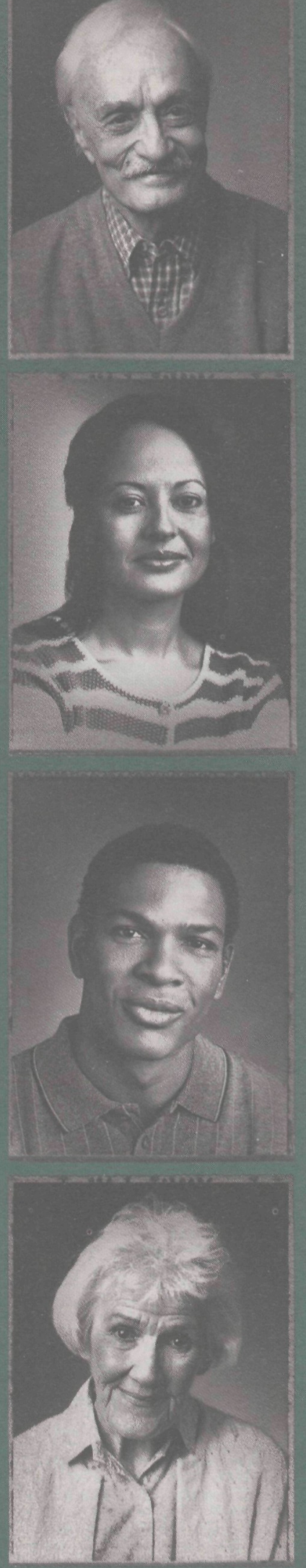


\section{Risperdal}

BEFOAE PAESCRENG PLEASE COHSULT COUPLETE PAESCA:BNG MDCATONS AN USACE

RISPEPDAL (iteperidone) is Indicated for the management of the manllestations of poychoitc disorders.

CONIRANDicatrons

RISPEPDAL' (isperidone) is contraindicated in patients with a known hypersensitivity to the product

WAPinnes

Neroleplic Nellonent Syntrom (Knis)

A potentilly fatal symptom complex sometimes refierred to as Neuroleptic (n) from NMS, the potential rentrioduction of diug therapy should be carefuly

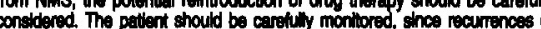
NMS have been reported.

Trotive D paldnech

A synctrome of potentially inoversible, moluntary, dystingetic movernents mey dovelop in patents treated with antipgychotic dugs. Whether antipsycho

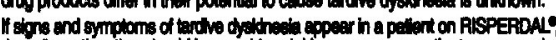

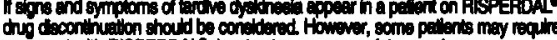

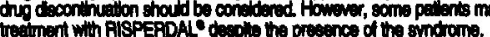

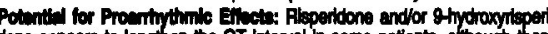
done appears to lengtien the OT Interval in some petients, although ther is no average increase in treated pationts, oven at 12-16 mg/dey, woll chovo the recormented does. Other drugs thet prolong the QT interval have been associated with the cocurrence of torsedes do pointes, a lio-threatening

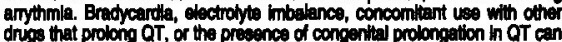
drugs that prolong QT, or the presences of conpentlal prol

increase the riak

Conent

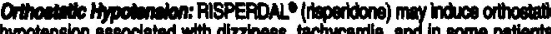
hypotension sescoclated wth dizzhess, tactycardia, and in some patients,

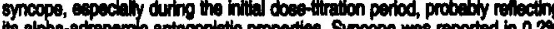

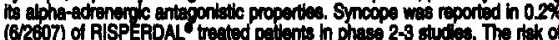

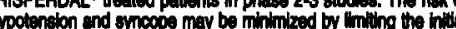
dose to $2 \mathrm{mg}$ total (Elther CD o $1 \mathrm{mg}$ BD, in nomal aduts and $0.5 \mathrm{mg}$ BD

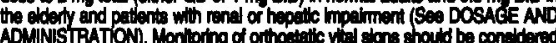

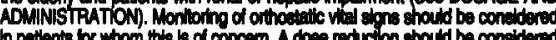
in pettents or whom this 18 of concem. A does roducion ahould be coneidered II hypotension occurs. RISPERDAL should be Leed with particular cartion in

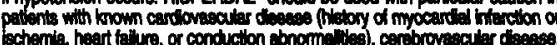

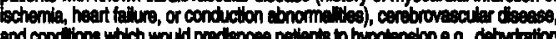

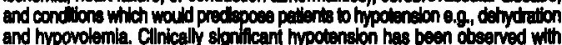
and hypovolemia. Clinically sion ificant hypotension has been observed

concomtant use of PISPERDAL end antifypertenewe modcation. selinures.

Dypheph: Esophageal dyemolity and asplration heve been aseociated with antipsyciotic chug use, Aspration pneumonla is a cormon cause of mortich and other antipeychotic drugs ahould be used cautiousty in patients at risk tor and other antipaychotic

Hyperprolectinomis: As with other drugs that antagonize dopamine D coceptors, itsperidone elevates prolectin levels and the elevation persists studies conducted to dale have shown an association between chronic

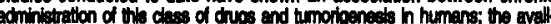
able ovidence ts considered too lintiled to be condusive at this the.

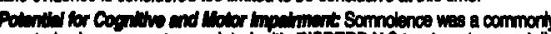

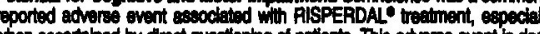
when ascertaned by drect questioning of petients. This adverse event is does related. Pationts should be cationed about operating hazandous mactinery, herapy does not aflect them adverse't.

Priplem: Rave cases of priapiem have been reported.

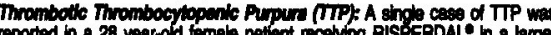
reportsd in a 28 year-old ternale petient rooking RISPERDAL In a large

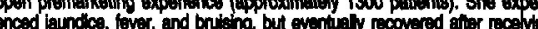
plasmepherests. The relationship to RISPERDAL' therapy is unksown.

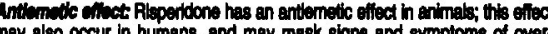
may also ocour in humans, and may mask signs and symploms of overdosage with certain drugss or of cand

Body Temperatur Aeguletion: Diaruption of body temperature requlation has been attributed to antipsychotlc agents. Caution is advised when

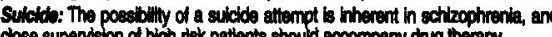
close supervision of high isik patients should accompany diug therapy.

Use in Pationte with Concomitemt thases: Clinical experience with RISPERDAL- in patients with certain concomitant systemlc illnesses is limited. Caution is advisable in using RISPERDAL in patients with d

Bectuves of the of orthostatic mpotension and QT prolongation, caution should be obeerved in candec pationts (See WAPNivGS and PPECCAUTIONS) Increased plasma concentrations of risperidone and 2-hydroxyrisperidon occur in patients with severe renal impaiment and in patients with sever Intormiton tos Pation

Physicians are advioed to consult tull prescribing intomation to review lasues to be discussed with patients for whom they prescribe RISPERDAL

Ory Interactions

The interactions of RISPERDAL $\bullet$ and other dung have not been systemet cally evaluated. Given the primary CNS ellects of tisperidone, caution should be used when RISPERDAL" is teken in combtration with other centrally acting diugs and aconol. RISPERDA may antegonize the effects of levodopa and dopamine agonists. Chronic administration of cartamazepine with risperidone

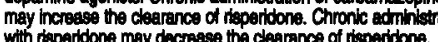

whith risperidone may decrease the clearance of rispenidone.

Fluoxedine may increase the plasma concentration of the anti-poychotic fraction done, although not the active matabolite, $y$ mydroxyrisperidone.

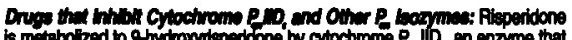

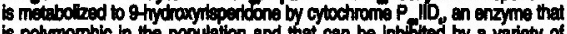
is polymorphic in the population and that can be inhibited by a variety of psychotiopic and other ougs (See CLNICAL PHARAMACOLOG h. Dng inter. acions that reduce the metabollsm of risperidone to gthydroxyrisperidone would increase the plasme concentrations of risperidone and lower the

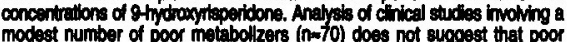
modest number of poor metabolzers $(n-70)$ does not suggest that poor and extenstve motabolizers have different rates of adverse

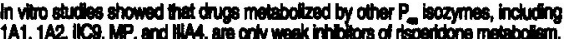

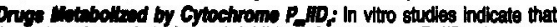

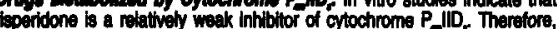

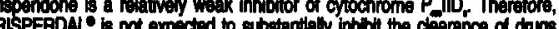
that are metebolized by this enzymatic pathway. However, cllnical data to confirm this axpectation are not avalable.

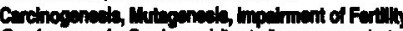

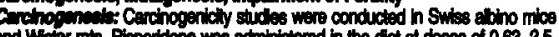
and Wistar rats. Fisperidone was actinistered in the dict at doces of 0.63,2.5,

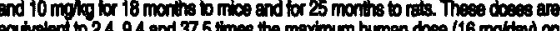

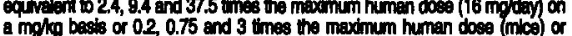

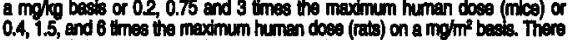

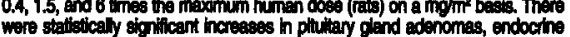
pencreas sdenomes and mammary glend adencearchnomes.

Thees fincings ere considered to be prolactin medcented. The relevance for human ithk of the findings of prolacth-mediated endocine tumors in rodents unvioin (See Hyperpoctnemia under PRECAUTIONS, GENERAL)

Mutegnesels: No evidence of mutagenic potential for ripperitone was lound.

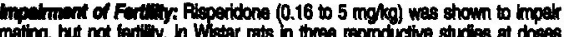
0.1 to 3 thes the maximum recornmendad human does on a mogme besh.

Prognency RISPERDAL" should be used during pregnency only if the potential benefit the potental the to the this

Lerer end Dellow

The Glect of RISPEPDAL on lebor and delvery in humans is unknoun.

Nuing liothers

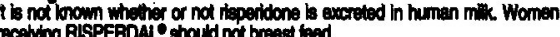
Poolletic Une

Sefoty and elfectivenese in chilitren heve not been cotablished.

Conimito In

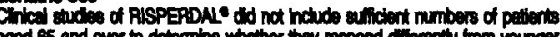

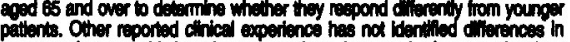

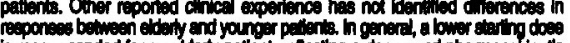

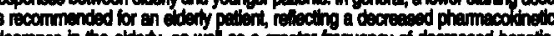

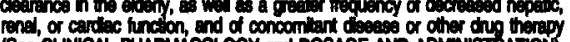

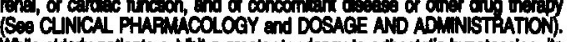

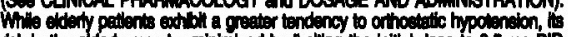

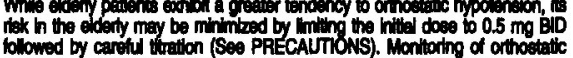
lollowed by carfoful turation (See PRECAUTIONS). Monttoring of orth

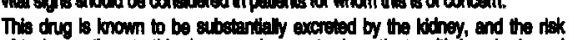
of loxk reactions to this chug mey be greder in pedtents with impaired renel hunction. Because elderly petients are more likely to have decreesed renal tunction, care should be taken in dooe selection, and I may
renal function (See DOSAGE AND ADMINISTRATION).

ADVEREE REACTION

Acocelated with Dtecentinution of Trutrien

Approximately $8 \%$ percent (244/2607) of AISPERDAL (ilependone)-treated patients in phase 2.3 studies discontinued treatment dus to an adverse event, more common events $(20.3 \%$ ) eseccided with discontituation and considered to be poselbly or probebly diug-releted included: extrapyramidal symptoms, Eatiness, hypertinesia, scomnolence, and nausea.

\section{netdeno in Controlled This}

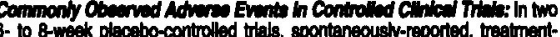
- to 8-week plecebo-controlled thals, spontaneously-reported, treatmentthe RISPERDAL Events win an inctience of 5\% or geater ho ai least one of somnolence, extrapyramidal symptoms, dizziness, constipation, neusea, dyspepsta, tintts, rash, and trohycandie.

Adverse everis were also elictied h one of theee two tries fi.e., in the ftredtose thal comparing RISPERDAL an does of 2, 6, 10, and 16 moldey with placebo) ut"izing a checktst for detecting soveres overits, a mothod that is more sensittve than spontaneous reporting. By thls method, the following

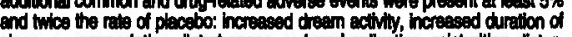
sleep, eccommodation disturitences, reduced salivation, micturtition disturdystunction, elaculatory dystunction, and ongastic dystunction.

The following edverse events occurred at an incldence of $1 \%$ of more, ano were at least as frequent among RISPERDAL treated pationts treated at doses of $510 \mathrm{mg} /$ day than among placebo-treated patients in the pooled

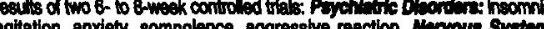
agitation, andily, somnolence, aggressive reaction. Nervous Syotem

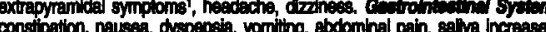

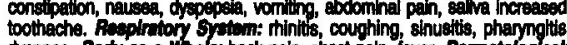
toothache. Acepiniony Syom: minits, coughing, sinusitis, pharynglits

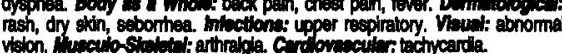

Includes tremor, dystonia, hypokinesia, hypertonia, hyperkinesia, oculogyic crisis, ataxia, abnomal galt, involunta

\section{Dose Dependoncy of Adveras Eventer.}

Data from two fixed dose trials provided evidence of dose-relatedness for axtrapyranidal symptoms associaled whith risperidon treatment. These sympms Include: sleepiness, increased duration of sloep, accommodation jeculatory dystunction, orgastlc dystunetion, asthenialassitude/ncreased ejaculatory dysunction, orgastic dystun.

Vivi Sin Change: RISPERDAL is associated with orthostatic hypotension and tachycardia (SEe PRECAUTONS).

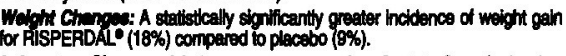

Laboritory Chengen: A between group compartson for 6- to 8-week plecebo differences in the proportions of patients experiencing potentialy important changes in routine senum chemisty, hematolory, or uthatyets parameters.

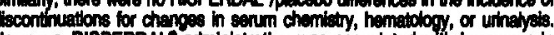
However, AISPERDAL admintstration was assoclated with increases in serum prolactin (See PRECAUTIONS).

ECE Channe: The electrocarlifograme of approximatoly 380 pettents who

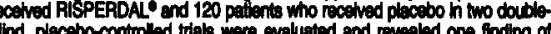

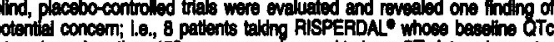
therval was less than 450 msec were observed to have OTc irtervals greater than 450 msec during treatment (See WARNINCS). Changes of this type were not been antong about

Other Events Observed During the Pro-llarkoting Evaluation of

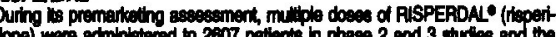
choling occumg in at least $1 / 100$ petients. Infrequent adveres events are those

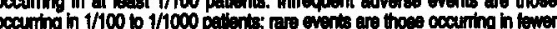

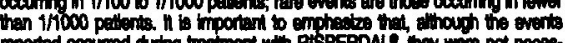
seported ocoumed of in

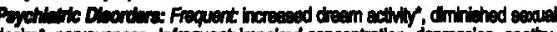

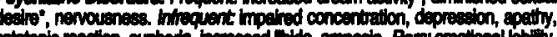

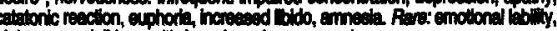

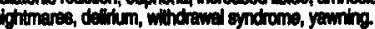

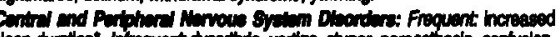

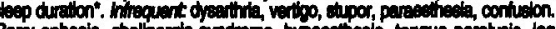

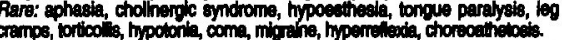
Cestro-Intecthal Dleordera: Frequent: anorexla, reduced salivation". Infrequent: flatulence, diarnea, increased appettis, stomattts, melena,

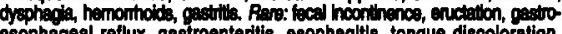
esophageal reflux, gastroentertis, esophaglts, tongue discoloration,
cholelithlasis, tongue edems, diverticultits, gholvis, discolored feces, GI cholelithlasis, tongise edem

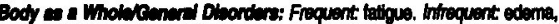
ipors, malalse, inthuenza-like symptoms. Rave: pallor, onlarged abdomen,

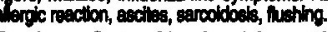

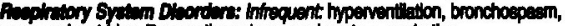
moumonia, stidor. Rare: asthma, horeased soutum, aeplation.

Sth end Appondy Dhondere: Frequent increesed plomentation", photosensitivity". Infrequent: increased sweating, acne, decreased sweating,

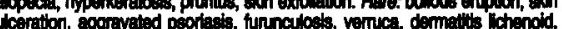
mypertichoeds, gential pruttus, urticarla.

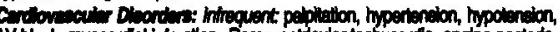

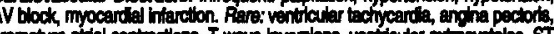
premeture atrial contractions,

Malon Diserdar: Intrequent: abnomed accommodation, xerophthamia. Rare: diptopla, eye pain, blepharitis, photopeia, photophoble, abnomal lectimation.

Munbolle and Nuthtiond Dicondens: Intrequent: hyponatremia, woight

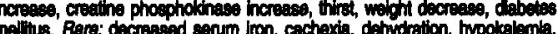
mypoproteinemia, hyperphosphatemila, hypertrigycoridemta, hyperuicemia, mpootycemia.

Urthery Syotem Disorders: Frequent: polyuria/polydipsia". Intrequent:

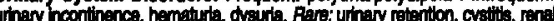
insulitioncy.

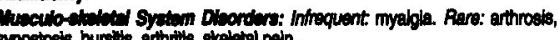

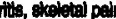

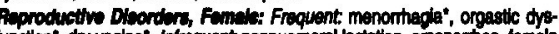
tunction", dy vagina". Inthoquent norpuerperal lactation, anenontiea, fenalo breast pain, leukortice, mastits, dysinenoritea, femelo perineal pein, intermenstrual bleading, vaginel hemomitege.

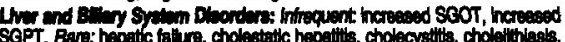
hepatids, hepetocellitar danege.

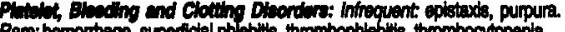

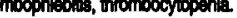

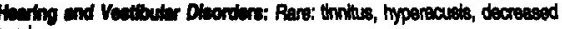
Aud Blood Call bleorders: Intrequent anemia, hypochromic anemia. Rare: nomocytic anemla.

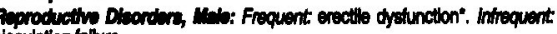
ejeculation tailure.

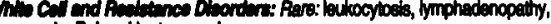
Eventhet anomaly.

Endoerins Disordura: Rare: gynecomastia, male breast pain, antidiuretc hormone deorder.

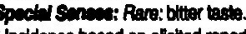

Poetintroduction Acports: Adverse events reported since market introduction which were temporally (but not necesserly causelly) related to RISPERDAL therapy, include the following: anaphylactic reection, anglosdema, apnea, atria fibrilation, cerebrovascular disorder, diabetas meilus agaravated, Inctuding diabetic ketoscidosis, Intoetinal obstucition, jaundico, There have been rare reoots of sudden degravatod, pulmonary emborism. in peltents receivth RISPERDALO. A causal relationsho with RISPERDAL has not been established. In is importent to note that sudien and unaxpected death may occur in psychotic patiants whether they remain untreated or whother they are treated with other antipeychotic diugs.

DRUO ABISE AND DEPENDEYCE

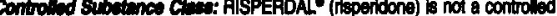
Gostance.

For Intormetion on symptome and trectunent of overdosags, ses tull precertiong Informetion.

More detalifod protessional information is avallable ypon requast.

- Janseen Phamaceutica inc. 1999

US Patent 4,804,683

7503217

JANSSEN

Titusville, NJ 08560 